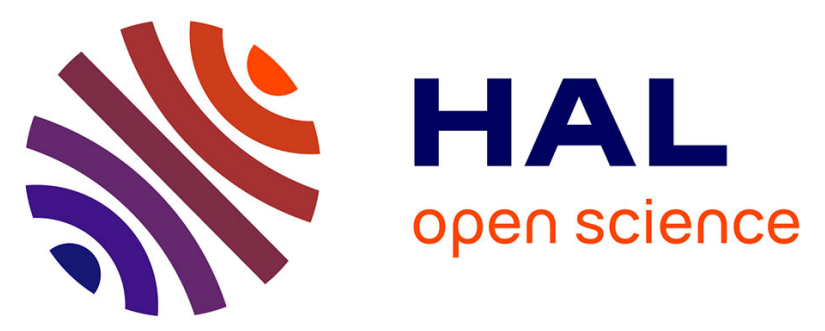

\title{
Gabaleryon, a new genus of widespread early Toarcian polychelidan lobsters
}

Denis Audo, M. Williams, S. Charbonnier, G Schweigert

\section{To cite this version:}

Denis Audo, M. Williams, S. Charbonnier, G Schweigert. Gabaleryon, a new genus of widespread early Toarcian polychelidan lobsters. Journal of Systematic Palaeontology, 2017, 15 (3), pp.205-222. 10.1080/14772019.2016.1167786 . hal-01313737

\section{HAL Id: hal-01313737 \\ https://hal-univ-rennes1.archives-ouvertes.fr/hal-01313737}

Submitted on 25 Apr 2017

HAL is a multi-disciplinary open access archive for the deposit and dissemination of scientific research documents, whether they are published or not. The documents may come from teaching and research institutions in France or abroad, or from public or private research centers.
L'archive ouverte pluridisciplinaire HAL, est destinée au dépôt et à la diffusion de documents scientifiques de niveau recherche, publiés ou non, émanant des établissements d'enseignement et de recherche français ou étrangers, des laboratoires publics ou privés. 
Journal of Systematic Palaeontology, Vol. 000, Issue 000, Month 2015, 000-000

\section{Gabaleryon, a new genus of widespread early Toarcian polychelidan}

\section{lobsters}

Denis Audo ${ }^{\mathrm{a}, \mathrm{c} *}$, Matt Williams ${ }^{\mathrm{b}}$, Sylvain Charbonnier ${ }^{\mathrm{c}}$ Günter Schweigert ${ }^{\mathrm{d}}$

a'Université de Rennes 1, EA 7316, 263 Avenue du Général Leclerc CS 74205, 35042 Rennes Cedex, France; ${ }^{b}$ Bath Royal Literary and Scientific Institution ; ${ }^{\mathrm{c}}$ Muséum national d'Histoire naturelle, Centre de Recherche sur la Paléobiodiversité et les Paléoenvironnements (CR2P, UMR 7207), Sorbonne Universités-MNHN, CNRS, UPMC-Paris6, 57 rue Cuvier, F75005, Paris, France; dStaatliches Museum für Naturkunde, Rosenstein 1, 70191 Stuttgart, Germany.

*Corresponding author. Email: denis.audo@edu.mnhn.fr

Polychelidan lobsters are decapod crustaceans with a unique anatomy: a dorsoventrally flattened carapace, four to five pairs of chelate appendages and a completely reduced rostrum. These crustaceans, like most other malacostracans are mostly preserved in outcrops in which exceptional preservation occurs, the Fossil-Konservat-Lagerstätten. Unfortunately, Lagerstätten are rare, and therefore disjointed both geographically and stratigraphically. This study focuses on a new genus of polychelidan lobster, Gabaleryon, with the description of two new species, Gabaleryon coquelae (Toarcian, France), and G. garassinoi (Toarcian, Italy). The long-standing question of the generic assignment of Eryon moorei (Toarcian, United-Kingdom) is herein solved and the species is ascribed to Gabaleryon. The occurrences of these three species and a fourth, Gabaleryon sp. 1 (Toarcian, Germany), provide a first palaeobiogeographic indication that the Fossil-Lagerstätten in which they occur were linked during Toarcian times. Besides, the occurrence of a possible fifth species of Gabaleryon in the late Bajocian - early Bathonian of France would extend the stratigraphic distribution of the new genus. Finally these new species increase our knowledge of the fossil polychelidans and place the Toarcian as their second peak of palaeobiodiversity, after that at the Kimmeridgian-Tithonian boundary.

Key words : Fossil-Lagerstätte, palaeobiogeography, Early Jurassic, Crustacea, Polychelida, Toarcian Oceanic Anoxic Event. 
D. Audo et al.

\section{Introduction}

Polychelidan lobsters (Polychelida) are fascinating decapod crustaceans characterized by an unusual morphology: a dorsoventrally flattened body, a complete reduction of rostrum and four to five chelae (up to three in other decapod crustaceans). Fossil polychelidan lobsters are almost exclusively known from Fossil-Lagerstätten - outcrops in which exceptional preservation occurs. For this reason, distribution of polychelidans is geographically and stratigraphically discontinuous. Though polychelidans occur abundantly from the Middle Triassic to Late Jurassic, they become extremely rare during the Cretaceous and then disappear from the fossil record. Yet, they are represented in modern environments by only one family, the Polychelidae Wood-Mason, 1874 (Fig. 1). Another discontinuity can be seen in their geographical distribution. While extant species are distributed worldwide (Galil 2000), fossil polychelidans seem mostly confined to Europe (e.g., Glaessner 1969; Garassino \& Schweigert 2006; Feldmann et al. 2013; Audo 2014; Audo et al. 2014a, 2014b, 2014c; Bravi et al. 2014); with very few occurrences outside Europe: Canada (1 specimen: Feldmann et al. 2013); India (1 specimen: Feistmantel 1877); Lebanon (2 larval specimens: Haug et al. 2015); Japan (5 specimens: Karasawa et al. 2003); and Siberia (5 specimens: Chernyshev 1930).

As with other crustaceans and arthropods (Wills 2001), these discontinuities are probably due to their low preservation potential. Indeed, the fossil diversity of polychelidans is almost entirely documented from their occurrences in Fossil-Lagerstätten (Fig. 1). The apparent fossil diversity of polychelidans clearly reaches a peak at the KimmeridgianTithonian boundary. This period coincides with the extensive deposition of plattenkalks, such as the celebrated Solnhofen-type outcrops, which have yielded many species of polychelidans (Oppel 1862; Garassino \& Schweigert 2006; Audo et al. 2014a, 2014b). The second peak in diversity occurs during the Sinemurian, with the deposits at Osteno (Italy: Pinna 1968, 1969; Teruzzi 1990) and Lyme-Regis (United Kingdom: Woods 1925), which also yielded many species of polychelidans. The third peak of polychelidans diversity occurs in the early Toarcian. Most early Toarcian polychelidan species are documented from the celebrated Holzmaden area and a few other German outcrops (Beurlen 1928, 1930, 1944; Kuhn 1952; Hauff \& Hauff 1981). Among these Toarcian species, many are assigned to the genus Proeryon Beurlen, 1928, which has a geographically wide range, since it occurs in Germany, France and Siberia (Audo 2014). 
In this study, we describe recently discovered specimens of Polychelida from the Toarcian of Brenoux (France) and reinvestigate closely allied species from rarely studied outcrops in France, England, Italy and Germany, all Toarcian in age. In addition, we studied one younger specimen from the late Bajocian - early Bathonian of Sennecey-le-Grand (France). Our new observations allow the description of one new genus and two new species. This taxonomic work improves our knowledge of polychelidan fossil diversity and allows us to study their palaeobiogeographic significance.

Institutional abbreviations. BRLSI, Bath Royal Literary and Scientific Institution, Bath, United Kingdom; MNHN.F, Collection de Paléontologie, Muséum national d'Histoire naturelle, Paris, France; MSNM, Museo civico di Storia naturale di Milano.

\section{Geological settings and stratigraphy}

All studied specimens were collected in five outcrops (Fig. 2) located in France (Brenoux), England (Strawberry Bank), Italy (two outcrops of Sogno Formation) and Germany (Engetal valley), which are all dated into the early Toarcian. An additional specimen from Sennecey-le-Grand (late Bajocian - early Bathonian, France) will also be considered.

\section{Brenoux}

Brenoux's outcrop lies at the north-eastern flank of the Balduc inlier, near the village of Brenoux (Lozère department, France, about $5 \mathrm{~km}$ of Mende). Rocks cropping out in Balduc are dated from the late Pliensbachian to the Aalenian (Coquel-Poussy 2013). Among these, the Toarcian sequence is mostly represented by the so-called schistes-carton: bituminous, thinly bedded calcareous marls. At the base of these marls, a greyish limestone bed occurs. A second limestone bed is intercalated within the marls, about one meter above the first one. The lower limestone bed (basal Toarcian) has yielded a beautifully preserved fauna including many fishes attributed to Leptolepis cf. coryphaenoides (Bronn, 1830), two polychelidans and a fragment of a cephalopod with its ink sac.

\section{Strawberry Bank}

The Strawberry Bank Lagerstätte yielded a diverse fossil fauna consisting of marine nektonic animals such as fish, crocodiles (Pierce \& Benton 2006), ichthyosaurs (Caine \& Benton 2011; Marek et al. 2015), cephalopods and crustaceans together with abundant insects from a nearby land mass (Williams et al. in press). The fossils are preserved in buff-coloured calcareous nodules composed of poorly sorted biomicritic mudstone. The fossils are generally 


\section{Audo et al.}

articulated and preservation is very fine; the vertebrates are typically three-dimensional (showing little or no compaction) and numerous delicate and soft tissue structures are preserved (Williams et al. 2015). However, this Lagerstätte is known from just one collection made in the 1840 s by Charles Moore from a quarry on the edge of the town of Ilminster, Somerset, England (Copp et al. 1999). Unfortunately the quarry was infilled in the late 1850s and its exact location is currently unknown. There is little or no local exposure, but fortunately Moore (1866) recorded the section, which alongside his collection held by BRLSI, enables precise lithostratigraphic correlation. Moore's extensive Strawberry Bank collection was largely ignored until the last decade (Williams et al. 2015), though at the time of writing the fossils were the subject of intense scientific scrutiny. Other comparable sites which preserve coeval faunas include Whitby in Northern England, Holzmaden in Southern Germany, and several sites in France (e.g. Charnay in South-East France) (Williams et al. 2015).

\section{Outcrops of Sogno Formation}

The Sogno ("the dream") Formation crops out on the southern flank of the mount Brughetto, ca $10 \mathrm{~km}$ southeast of Lecco, Province of Lecco, Lombardy, Italy, and on the southern flank of the mount Cornizzolo ( $c a 8 \mathrm{~km}$ southwest of Lecco). During Toarcian, the Sogno Formation was deposited on the edge of the Trento Plateau. Three lithologies are recognized in this formation; the basal one is dated into the early Toarcian (Tenuicostatum ammonite biozone) and yields a varied fauna including exceptionally preserved fossils (Tintori 1977; Gaetani \& Poliani 1978; Garassino \& Teruzzi 2001; Schweigert et al. 2003; Garassino \& Gironi 2005; Delfino \& Dal Sasso 2006). This fauna comprises actinopterygian fishes (Leptolepis coryphaenoides, Pachycormus sp., Pholidophorus sp.), a marine reptile (possibly Pelagosaurus Bronn, 1842), crustaceans (?Antrimpos Münster, 1839, Gabaleryon garassinoi nov. gen., nov. sp., Uncina alpina Schweigert et al., 2003, ?Etallonia Oppel, 1861), bivalves (Bositra sp.), cephalopods (see Tintori 1977) and fragments of terrestrial plants (see Tintori 1977).

\section{Engetal valley}

The studied specimen from the Northern Calcareous Alps comes from the middle part of the Allgäu Formation (today part of the Austroalpine Allgäu Nappe), which includes dark, bituminous, sometimes manganiferous shales (so-called Manganschiefer). These bituminous shales can be dated with the help of some ammonites listed by Jacobshagen (1965) as early Toarcian in age. The exact locality is situated in the Engetal valley, southwest of the town of 
Pfronten, in the southernmost part of Germany, ca 2 kilometres north of the Austrian border. Besides the new specimen of polychelidan lobster, a single chela of Uncina alpina Schweigert, Garassino, Hall, Hauff \& Karasawa, 2003 was found at this locality. Although these finds point to some potential for exceptional preservation, the locality was never systematically sampled.

\section{Sennecey-Le-Grand}

The outcrop lies about $2 \mathrm{~km}$ south of the town of Sennecey-le-Grand (Saône-et-Loire department, France). This outcrop is mostly known for yielding beautifully preserved echinoderms (Meyer 1990), including articulated asteroids, ophiuroids and crinoids (Lang 2012); but is still poorly documented in scientific literature. The outcrop belongs to the Marnes à Acuminata Formation which is dated into the late Bajocian - early Bathonian (Pellenard et al. 1998).

\section{Material and methods}

\section{Examined material}

In total, 23 specimens were used in this study:

- 2 specimens collected from the base of Toarcian at Brenoux (Lozère Department, France) by Nathalie Coquel-Poussy (specimen MNHN.F.A51506 and one housed in Nathalie Coquel-Poussy's private collection).

- 1 specimen of Eryon moorei Woodward, 1866 (holotype: BRLSI M1247) from Ilminster (Somerset, United Kingdom), historically collected by Charles Moore.

- 19 specimens ascribed to Proeryon hartmanni (Meyer, 1836) (Garassino \& Gironi 2005), from the Sogno formation at mount Cornizzolo (MSNM i26211-i26216, i26218, i26220, i26221, i26223-i26225, i26227, i26233-i26237, i26284.

- 1 specimen ascribed to Coleia cf. banzensis Kuhn, 1952 (Garassino \& Teruzzi 2001), from the Sogno formation at mount Brughetto (MSNM i10850).

\section{Imagery}

The study of the holotype of Eryon moorei and the specimen of Coleia $\mathrm{cf}$. banzensis are based on high-resolution pictures. Specimens from Brenoux and mount Cornizzolo were imaged using cross-polarized lights and/or UV fluorescence photography. These techniques help achieving a greater contrast between the fossil and matrix either by removing most 
D. Audo et al.

surface reflection (cross-polarization) or by fluorescence of mineral occurring in the fossil (yellow fluorescence under UV light).

\section{Systematic palaeontology}

Class Malacostraca Latreille, 1802

Order Decapoda Latreille, 1802

Suborder Pleocyemata Burkenroad, 1963

Polychelida Scholtz \& Richter, 1995

Superfamily Eryonoidea Haan, 1841

Family Coleiidae Van Straelen, 1925

Genus Gabaleryon nov, gen.

Included species. Gabaleryon coquelae nov. sp., Gabaleryon garassinoi nov. sp., Gabaleryon moorei (Woodward, 1866) nov. comb.

Type species. Gabaleryon coquelae nov. sp.

Occurrence. Toarcian (France, England, Italy, Germany) - late Bajocian - early Bathonian (France) (?).

Etymology. A combination of the Gabali, Gallic tribe that inhabited the region, where the type species occurs and Eryon Desmarest, 1817, generic name for the first described species of Polychelida Scholtz \& Richter, 1995.

Diagnosis. Dorsoventrally flattened carapace, with an ovoid outline in dorsal view; ocular incision widely open laterally; cervical and postcervical incisions forming minute indentations of lateral margin; axial carina on pleonites 2 to 5 cut by the deep posterior transverse groove; very rounded scaphocerite.

Comments. Gabaleryon nov. gen. is ascribed to Polychelida by its four pairs of chelate pereiopods, its dorsoventrally flattened carapace and the absence of rostrum, which is replaced by a concave frontal margin (Fig. 3F). It is distinguished from all other polychelidan genera by its unique combination of characters. It differs from all genera of polychelidan lobsters, with the exception of Proeryon Beurlen, 1928 (Coleiidae), Willemoesiocaris Van Straelen, 1925 (Coleiidae), Palaeopolycheles Knebel, 1907 (Coleiidae), and Tethyseryon Bravi et al., 2014 (Coleiidae), by an axial carina on pleonal terga cut by posterior transverse groove (Fig. 3). It differs from all these genera by very shallow cervical and postcervical incisions (Fig. 3). Furthermore, it differs from Willemoesiocaris and Palaeopolycheles by its short anterolateral angle (Fig. 3). Gabaleryon nov. gen. seems phylogenetically related to 
Proeryon. Indeed, it possesses characteristics also known in Proeryon: a short anterolateral angle, a wide and rounded scaphocerite and pleonal terga with an axial carina cut by posterior transverse groove. Proeryon is currently ascribed to Coleiidae. For this reason, it seems reasonable to place Gabaleryon within the same family. However, we point out that the diverse Coleiidae are considered as possibly paraphyletic (Audo et al. 2014c) and the familial assignment of Gabaleryon may change.

Gabaleryon coquelae nov. sp.

Figs 3F, 4

2013 Eryon sp.; Coquel-Poussy: 10-13, figs 10-11.

Etymology. The specific epithet honours Nathalie Coquel-Poussy, who discovered the type material and introduced it to the scientific community.

Type material. Holotype with part and counterpart of a flattened, subcomplete specimen in dorsal view (MNHN.F.A51506); Paratype with part and counterpart of a flattened, subcomplete specimen in ventral view (N. Coquel-Poussy's private collection).

Type locality. Brenoux (Lozère department, France).

Type age. Early (basal) Toarcian (Coquel-Poussy 2013).

Occurrence. Hitherto only known from the type locality.

Diagnosis. Dorsoventrally flattened carapace, with an ovoid to subrectangular outline in dorsal view; ocular incision widely open laterally; shallow cephalothoracic grooves; postcervical groove effaced or absent between branchial carina and median line; cervical and postcervical incisions forming minute indentations of lateral margin; axial carina on pleonites 2 to 5 cut by deep posterior transverse groove; very rounded scaphocerite; first pereiopod with long palm; long uropod.

Description.

Shape of carapace. - Dorsoventrally flattened carapace, with ovoid outline in dorsal view; concave frontal margin; short anterolateral angle; lateral margin cut by ocular, cervical and postcervical incisions; large ocular incision widely open laterally and closed ventrally; anterolateral margin slightly convex, subparallel to longitudinal axis; cervical and postcervical incisions opening in the first half of the lateral margin; very small cervical incision; straight mediolateral margin slightly shorter than anterolateral margin; very small postcervical incision; posterolateral margin slightly convex; rounded posterolateral angle, contiguous with pleon, extending shortly along first pleonite; concave posterior margin, wider than frontal margin. 


\section{Audo et al.}

Carinae and grooves of carapace. - Postrostral and postcervical carinae separated by cervical groove; slightly raised postrostral and postcervical carinae, poorly preserved; postorbital carina not visible; branchial carina extending anteriorly from posterolateral angle toward ocular incision cut by postcervical and cervical grooves, not reaching ocular incision; shallow and curved cervical groove cutting deeply median line in the middle of carapace length; shallow and transverse postcervical groove, not preserved between branchial carina and median line.

Pleon and telson. - Pleon and telson slightly longer than carapace; pleon slightly narrower than carapace; pleonite 1 poorly preserved; pleonites 2-6 of decreasing width; tergum of pleonites 2 to 6 crossed by a pair of transversal grooves converging medially and cutting axial carina, anterior one being slightly deeper than the other and separated from pleonite anterior margin by a slightly cambered zone; pleonites 2-5 tergopleura not preserved; subtriangular telson strengthened by two longitudinal carinae.

Eye and cephalic appendages. - Large eye slightly projected from ocular incision; antennula not preserved; antenna with short basipodite carrying (1) very rounded scaphocerite strengthened by median carina and (2) endopod forming a long flagellum measuring about one third of carapace length; other cephalic appendages not preserved.

Thoracic appendages. - Third maxilliped with reniform ischium, and stout merusdactylus; first pereiopod distinctly larger than others, with dactylus and pollex strongly curved distally, palm as long as dactylus and subtriangular carpus; chelate pereiopods 2-4 decreasing in size distally, with dactylus and pollex slightly shorter than palm and slightly curved distally; pereiopod 5 not preserved.

Pleonal appendages. - Pleopods 1-5 not preserved; uropods with short basipodite carrying (1) elongate uropodal exopod, almost as long as telson, strengthened by longitudinal carina and distally cut by diaeresis and (2) rounded uropodal endopod, almost as long as telson, strengthened by longitudinal carina.

Ornamentation. - Pleonal tergum covered by numerous tubercles between anterior and posterior transverse grooves, not preserved elsewhere.

Gabaleryon moorei (Woodward, 1866) nov. comb.

Fig. 5

1866 Eryon moorei Woodward: 499-500, pl. 25 fig. 3.

1877 Eryon moorei Woodward; Woodward: 11.

1881 Eryon moorei Woodward; Woodward: 530.

1888 Eryon moorei Woodward; Spence Bate: 116. 
1891 Eryon moorei Woodward; Krause: 176.

1911 Eryon moorei Woodward; Woodward: 307.

1924 Eryon moorei Woodward; Balss: 175.

1925 Eryon moorei Woodward; Van Straelen: 119.

1925 Coleia moorei (Woodward); Woods: 21, pl. 5 fig. 5.

1929 Proeryon moorei (Woodward); Glaessner: 340.

1952 Proeryon moorei (Woodward); Kuhn: 159.

2005 Proeryon moorei (Woodward); Garassino \& Gironi: 59.

2006 Coleia moorei (Woodward); Garassino \& Gironi: 95.

2007 Coleia moorei (Woodward); Teruzzi \& Garassino: 95.

2010 Coleia moorei (Woodward); Schweitzer et al.: 44.

Type material. Holotype by monotypy (BRLSI M1247), part of flattened, subcomplete specimen in dorsal view.

Type locality. Strawberry Bank (Ilminster, Somerset, United Kingdom).

Type age. Early Toarcian (Serpentinum ammonite biozone; Woods 1925).

Occurrence. Hitherto only known from the type locality.

Emended diagnosis. Dorsoventrally flattened carapace, with ovoid outline in dorsal view; ocular incision widely open laterally; deep cephalothoracic grooves; postcervical groove marked between branchial carina and median line; cervical and postcervical incisions forming minute indentations of lateral margin; axial carina on pleonites 2 to 5 probably cut by deep posterior transverse groove; first pereiopod with stocky palm; uropods as long as telson, with uropodal exopod cut by very rounded diaeresis.

\section{Description.}

Shape of carapace. - Dorsoventrally flattened carapace, with ovoid outline in dorsal view; concave frontal margin; short anterolateral angle; lateral margin cut by ocular, cervical and postcervical incisions; large ocular incision widely open laterally; anterolateral margin slightly convex, subparallel to longitudinal axis; cervical and postcervical incisions opening in first half of lateral margin; very small cervical incision; straight mediolateral margin slightly shorter than anterolateral margin; very small postcervical incision; posterolateral margin slightly convex; rounded posterolateral angle, contiguous with pleon, extending shortly along first pleonite; concave posterior margin, wider than frontal margin.

Carinae and grooves of carapace. - Postrostral carina not preserved; postcervical carinae strongly raised posteriorly; postorbital carina not visible; branchial carina extending anteriorly from posterolateral angle toward ocular incision cut by postcervical and cervical 


\section{Audo et al.}

grooves, not reaching ocular incision; deep and curved cervical groove cutting deeply median line in middle of carapace length; deep postcervical groove, extending transversally from postcervical incision toward branchial carina, shallower from branchial carina to median line, curving slightly forward near median line, not cutting median line.

Pleon and telson. - Pleon and telson slightly longer than carapace; pleon slightly narrower than carapace; pleonite 1 shorter than others; pleonites 1-5 with subrectangular terga; pleonite 6 with subtrapezoidal tergum; tergum of pleonites 2 to 6 crossed by pair of transversal grooves converging medially; pleonites 2-5 with lanceolate tergopleura, poorly preserved; pleonite 6 with narrow tergopleura; subtriangular telson strengthened by two longitudinal carinae.

Eye and cephalic appendages. — Not preserved

Thoracic appendages. - Large pereiopod 1; pereiopod 1 palm stout, slightly longer than dactylus, with curved outer margin; other pereiopods not preserved.

Pleonal appendages. - Pleopods 1-5 not preserved; uropods with short basipodite carrying (1) elongate uropodal exopod, strengthened by longitudinal carina and distally cut by strongly curved diaeresis and (2) rounded uropodal endopod, almost as long as telson, strengthened by longitudinal carina.

Ornamentation. - Pleonal tergum covered by fine tubercles between anterior and posterior transverse grooves, not preserved elsewhere.

Comments. Eryon moorei possesses an ovoid carapace in outline in dorsal view, an ocular incision widely open laterally, very small cervical and postcervical incisions and posterior transverse groove on pleonites cutting median line. All these characters are diagnostic of Gabaleryon nov. gen. and justify the assignment of Eryon moorei to this genus. Gabaleryon moorei nov. comb. differs from G. coquelae nov. gen., nov. sp. by its slightly deeper cephalothoracic grooves (shallower in G. coquelae), a postcervical groove between marked branchial carina and median line (effaced or absent in G. coquelae), a first pereiopod with palm slightly stockier and with more curved margins (more slender and with straight margins in G. coquelae) and shorter uropodal endopod and exopod (longer in G. coquelae). It also differs from Gabaleryon garassinoi nov. gen., nov. sp. by a more ovate carapace (subrectangular in G. garassinoi) a slightly shorter carapace (slightly shorter than pleon and telson; carapace as long as pleon and telson in G. garassinoi) and uropodal endopod and exopod shorter than the telson (longer than the telson in G. garassinoi). 
Figs 6-7

2001 Coleia cfr. banzensis Kuhn; Garassino \& Teruzzi: 190-191, fig. 3.

2005 Proeryon hartmanni (Meyer); Garassino \& Gironi: 56-63, figs 4-9.

Etymology. The specific epithet honours Alessandro Garassino, who was the first palaeontologist to study the fossil crustaceans from the Sogno Formation, Lombardy, Italy.

Type material. Holotype from mount Cornizzolo with part of a flattened, subcomplete specimen in dorsal view (MSNM i26215). - 18 paratypes from mount Cornizollo: MSNM i26211-i26214, i26216, i26218, i26220, i26221, i26223-i26225, i26227, i26233-i26237, i26284. - 1 paratype from mount Brughetto: MSNM i10850.

Type locality. Sogno Formation of mount Cornizzolo (Province of Lecco, Lombardy, Italy).

Type age. Early Toarcian (Tenuicostatum ammonite biozone after Tintori 1977).

Occurrence. Early Toarcian of Sogno Formation (mounts Cornizzolo and Brughetto; Province of Lecco, Lombardy, Italy)

Diagnosis. Dorsoventrally flattened carapace, with subquadrate outline in dorsal view; ocular incision widely open laterally; deep cervical groove; postcervical groove faint between branchial carina and median line; cervical and postcervical incisions forming minute indentations of lateral margin; axial carina on pleonites 2 to 5 cut by posterior transverse groove; short telson, very rounded scaphocerite; first pereiopod with stocky palm, elongate uropods with exopod cut by very curved diaeresis.

\section{Description.}

Shape of carapace. - Dorsoventrally flattened carapace, with subrectangular outline in dorsal view; concave frontal margin; short anterolateral angle; lateral margin cut by ocular, cervical and postcervical incisions; large ocular incision widely open laterally; anterolateral margin slightly convex, subparallel to longitudinal axis; cervical and postcervical incisions opening in first half of lateral margin; very small cervical incision; straight mediolateral margin slightly shorter than anterolateral margin; very small postcervical incision; posterolateral margin slightly almost straight; subquadrate posterolateral angle, contiguous with pleon, extending shortly along first pleonite; concave posterior margin, wider than frontal margin.

Carinae and grooves of carapace. - Well-marked postrostral carina not reaching anterior margin; well-marked postcervical carina extending from cervical groove to posterior margin; postorbital carina poorly preserved; well-marked branchial carina extending anteriorly from posterolateral angle toward cervical grooves; deep and curved cervical groove 


\section{Audo et al.}

cutting deeply median line in middle of carapace length; deep postcervical groove, extending transversally from postcervical incision toward branchial carina, very shallow (and poorly preserved) from branchial carina to median line; shallow branchiocardiac groove, extending along branchial carina and curving posteriorly toward median line.

Pleon and telson. - Pleon and telson as long as carapace; pleon slightly narrower than carapace; pleonite 1 slightly shorter than others; pleonites 1-5 with subrectangular terga; pleonite 6 with subtrapezoidal tergum; tergum of pleonites 2 to 6 crossed by pair of transversal grooves converging medially; pleonites 2-5 with lanceolate tergopleura, poorly preserved; pleonite 6 with tergopleura narrow; subtriangular telson strengthened by two longitudinal carinae.

Eye and cephalic appendages. — Large eye slightly projected from ocular incision; antennula not preserved; antenna with short basipodite carrying (1) very rounded scaphocerite strengthened by median carina and (2) endopod with a poorly preserved flagellum.

Thoracic appendages. - Large pereiopod 1; pereiopod 1 palm stout, slightly shorter than dactylus, with curved outer margin; chelate P2-P4, smaller than P1, poorly preserved.

Pleonal appendages. - Pleopods 1-5 not preserved; uropods with short basipodite carrying (1) elongate uropoal exopod, longer than telson, strengthened by longitudinal carina and distally cut by strongly curved diaeresis and (2) rounded uropodal endopod, longer than telson, strengthened by longitudinal carina.

Ornamentation. - Carapace covered with fine tubercles; pleon covered by slightly coarser tubercles.

Comments. Polychelidans from Sogno Formation were initially interpreted as Coleia cf. banzensis by Garassino \& Teruzzi (2001) based upon the shape of specimens from mount Brughetto. Later, Garassino \& Gironi (2005) provided new material from another outcrop of the same formation in mount Cornizzolo and assigned all specimens to Proeryon hartmanni (Meyer, 1836) based upon the shape of carapace, serration of lateral margin, presence of a diaeresis and carapace grooves (note that the branchiocardiac groove identified by Garassino \& Gironi (2005) is herein considered as postcervical groove). Our reinvestigation of the wellpreserved specimens from mount Cornizzolo and one from mount Brughetto leads us to a different conclusion. The new species differs clearly from species of Proeryon by its subrectangular carapace (more or less pyriform in Proeryon species), its shallow cervical and postcervical incisions (deeper in Proeryon species). The new species possess an ovoid, almost subquadrate carapace in outline in dorsal view, an ocular incision widely open laterally, very small cervical and postcervical incisions, posterior transverse groove on pleonites cutting 
median line and a very rounded scaphocerite. All these characters are diagnostic of Gabaleryon nov. gen. and justify the assignment to this genus. Gabaleryon garassinoi nov. sp. differs from G. coquelae and G. moorei by its subquadrate carapace (more ovate in G. coquelae and G. moorei), its postcervical groove shallow between both branchial carinae (well-marked in G. moorei, effaced or absent in G. coquelae), its P1 palm stockier and with slightly more curved margin (slightly more elongated and with straight margins in G. coquelae), its short telson (more elongated in G. coquelae) and longer uropodal endopod and exopod (shorter in G. moorei).

\section{Gabaleryon sp. 1}

Fig. 8A

Examined material. One specimen, part and counterpart (Tobias Klöck's and Giuseppe Gulisano's private collections).

Occurrence. Early Toarcian of Engetal valley (Allgäu Formation) near Pfronten, southernmost Germany.

Description. Dorsoventrally flattened carapace with concave frontal margin, and lateral margin cut by large ocular incision. Pleon and telson about as long as carapace; pleonite 1 slightly shorter than others; pleonites 4 to 6 crossed by an axial carina and a pair of transverse grooves, the posterior one cutting axial carina. Telson subtriangular, strengthened by pair of longitudinal carinae. First pereiopod large, with palm with straight margins, dactylus and pollex as long as palm. Uropod poorly preserved, about as long as telson; uropodal exopod with curved diaeresis.

Comments. This specimen is assigned to Gabaleryon nov. gen. on the basis of its ovoid carapace, its posterior transverse groove cutting the axial carina on pleonal terga and its uropodal exopod with curved diaeresis. The straight P1 palm is similar to that of Gabaleryon coquelae, and differs from those of G. garassinoi nov. sp. and G. moorei nov. comb., which are more curved. This specimen preserves a spiny crest along P1 carpus. Such a crest is lacking or not preserved in G. coquelae - due to a poor preservation of carpus - and lacking in G. garassinoi and G. moorei. In addition, the generally poor preservation of the lateral margins of the carapace due to its superposition with first pereiopods does not allow, in our opinion, to compare further this specimen with other species of Gabaleryon or to describe it as new species. The occurrence of this specimen in southernmost Germany is important as it extends the known palaeogeographic range of Gabaleryon.

?Gabaleryon sp. 2

Fig. 8B 
Examined materiel. One specimen (David Gluck's private collection).

Occurrence. Late Bajocian - early Bathonian of Sennecey-le-Grand, Eastern France.

Description. Dorsoventrally flattened carapace, ovoid in outline in dorsal view, poorly preserved. Pleon about as long as carapace; s1 slightly shorter than others; s2-s6 crossed by a pair of transverse grooves cutting median line. First pereiopod large, with stout palm with curved lateral margins; P1 dactylus and pollex incompletely preserved.

Comments. This specimen displays an ovoid carapace and axial carina on pleonites 2 to 5 cut by the deep posterior transverse groove. These characteristics are typical of Gabaleryon. However, it is not possible to assess the presence of a diaeresis nor the shape of the frontal margin. For these reasons, we cannot assign with confidence this specimen to Gabaleryon. It shall also be noted that the chela of first pereiopod seems by far stouter than that of other species.

The occurrence in the late Bajocian - early Bathonian of a specimen with a morphology rather similar to that of Toarcian species of Gabaleryon suggests that this morphotype may have survived for $15 \mathrm{Ma}$.

\section{Discussion}

\section{The Toarcian in Europe}

During the Toarcian, most of Western Europe, including all the localities cited herein, was covered by a relatively shallow epicontinental sea at the then North-Western margin of the Tethys Ocean (Golonka 2007). The early Toarcian was marked by a global anoxic event (T-OAE) indicated by a carbon isotope excursion lasting between 0.3 and $0.6 \mathrm{Ma}$ (Boulila et al. 2014; Huang \& Hesselbo 2014) reaching its peak in the Falciferum subzone (183 Ma), after the deposition of the Sogno Formation and Brenoux outcrops, and approximatively when the Strawberry Bank Lagerstätte was deposited (Williams et al., in press). The Engetal valley outcrop was deposited around the time when T-OAE occurred, in the early Toarcian. However, its relation with the T-OAE is not precisely known, since this outcrop is not currently dated precisely enough. Resulting from the volcanic activity of the Karoo-Ferrar igneous province and/or destabilization of gas hydrates (Emmanuel et al. 2006), the T-OAE was associated with up to $4 \mathrm{Ma}$ of oceanic temperature fluctuation and other climatic perturbations resulting in substantially elevated marine global extinction rates (Little et al. 1995; Wignall et al. 2005; Suan et al. 2010): approximately 5\% of families and $26 \%$ of genera (Danise et al. 2015) most notably amongst the ammonites (Macchioni \& Cecca 2002), 
the brachiopods (Vörös 2002; García Joral et al. 2011), and the foraminifera (Caruthers et al. 2013).

\section{Distribution of Toarcian polychelidans}

With the addition of the species described herein, the Toarcian is now recognized as the second peak of fossil diversity of polychelidan lobsters, with 5 genera and 10 species (8 genera and 15 species for Kimmeridgian-Tithonian; 4 genera and 9 species for Sinemurian) (Fig. 1).

Toarcian polychelidans can be divided into five main taxa:

1. Gabaleryon with the four herein described taxa, from France, United Kingdom, Italy and Germany;

2. Proeryon, with Proeryon hartmanni (Meyer, 1836), P. hauffi Beurlen, 1944, P. laticaudatus Beurlen, 1928, and P. zehentbaueri Audo, Schweigert, Saint Martin \& Charbonnier, 2014 from Germany (see species listed in Audo et al. 2014c), E. calvadosii Morière, 1883 (probably a Proeryon, judging from the shape of carapace) from France and Proeryon viluensis Chernyshev, 1930 from Siberia - these last two species are considered to be junior synonyms of P. hartmanni by Audo (2014).

3. "Coleia" sinuata Beurlen, 1928;

4. "Palaeopolycheles" crymensis Levitski, 1974;

5. Eryon sibiricus (Chernyshev, 1930) (see Audo 2014 for generic assignment).

All of these species, except "Palaeopolycheles" crymensis (from the Toarcian-Aalenian boundary), date from the early Toarcian. This suggests that the early Toarcian, despite its biological crisis, was rather favourable to the preservation of polychelidans or/and to their diversification. In fact, Gabaleryon coquelae nov. gen., nov. sp. and G. garassinoi nov. sp. occur just before or at the beginning of the T-OAE anoxic event; G. moorei occurs during TOAE.

Several reasons may explain the abundance of polychelidan lobsters in early Toarcian: it is possible that the preservation of crustacean carcasses was favoured by a low oxygenation of the seawater. A diversification of polychelidan lobsters is also possible, perhaps linked with the extinction of competitors and/or predators. If true, it would imply a trend opposed to that of other animal taxa which suffered from the extinctions during the T-OAE event. Unfortunately, it is currently impossible to test these hypotheses due to the lack of quantitative information on polychelidans in the fossil record. 
D. Audo et al.

\section{Palaeoecology}

Most studied specimens are complete and in anatomical connection, including the articulation between cephalothorax and pleon, which is one of the first to break (Allison 1986; 1988; Plotnick 1986). This preservation suggests little to no post-mortem transport, which implies that polychelidans were probably autochthonous or parautochthonous to their burial environments. It is quite possible that some or all of these Toarcian polychelidan lobsters were tolerant to hypoxic or even anoxic conditions, with factors such as food availability being more significant factors in their distribution. It has been demonstrated that this can be the case with modern decapod crustacean communities (Hendrickx 2001) and at Strawberry Bank, which was an anoxic depositional environment, there is at least one example of a fish (BRLSI.M1389), which shows indications of scavenging that could only be attributed to a decapod crustacean. Many extant polychelidans are opportunistic scavengers (Firth \& Pequegnat 1971; Lagardère 1973; Gore 1984; Cartes \& Abelló 1992) and hence it seems likely that they may have contributed to the scavenging of fish remains in Strawberry Bank.

\section{Palaeobiogeography}

The localities where Gabaleryon occurs are scattered across Western Europe and were deposited in slightly different contexts (Fig. 2):

- Brenoux was deposited under the shallow Toarcian epicontinental sea, near several small islands; no terrestrial fauna has been documented there yet. This locality dates from the early Toarcian, but its precise ammonite biozone is unknown.

- Strawberry Bank was deposited in a similar context, except it was closer to the large landmass of the London-Brabant Massif and preserves an abundant terrestrial fauna. This locality is perhaps the youngest (Serpentinum biozone, Falciferum subzone).

- The Sogno Formation outcrops were deposited on the edge of the Trento Plateau separated from the others by the land mass of Corsica-Sardinia and a narrow deep basin. This locality is slightly older than Strawberry Bank.

- The siliciclastic claystones of the Engetal valley (Allgäu Formation) accumulated in moderately deep basins, which developed after the drowning of the previously developed carbonate platforms of the Northern Calcareous Alps. In the early Toarcian, the widespread Anoxic Event effected these deposits and led to temporary oxygen depletion at the sea floor.

Despite these differences, the Sogno Formation and Strawberry Bank are associated by their vertebrate faunas, with the occurrences in both outcrops of the fishes Pachycormus 
Agassiz, 1833, Leptolepis Agassiz 1833 and Pelagosaurus Bronn, 1842. Leptolepis also occurs in Brenoux, however, this genus needs to be reviewed (Coquel-Poussy 2013) and therefore is currently not a good palaeobiogeographical proxy.

The description of Gabaleryon nov. gen. from Brenoux, Strawberry Bank and Sogno Formation provides additional palaeobiogeographical evidence linking France, United Kingdom and Italy. The occurrence of one species of Gabaleryon in each of these localities possibly indicates limited provincialism. Indeed, G. coquelae nov. sp., G. moorei nov. comb. and G. garassinoi nov. sp. are closely allied species.

Gabaleryon is therefore a relatively widespread genus of polychelidan, occurring from United Kingdom to Germany. Indeed, by comparison, most other polychelidan lobster genera are either documented from a single outcrop or geographically close outcrops. Only two other genera have a greater palaeogeographic distribution: Coleia Broderip, 1835, which still first occur in the Carnian of Japan (Karasawa et al. 2003) and occurs later in Europe (Glaessner 1969), but require to be reinvestigated; and Proeryon Beurlen, 1928, which occurs from France to Siberia during Toarcian.

\section{Conclusions}

The description of a new genus and two new species improves our knowledge of the fossil diversity of polychelidan lobsters. The assignment of Eryon moorei Woodward, 1866 to a new genus, also shows that the diversity of polychelidans has for a long time been underestimated. Above all, the precise taxonomic identification of these fossils allows us to link four widely separated outcrops.

At the time of writing, a single phylogeny (Ahyong 2009) has been proposed to assess relationships between polychelidans. This phylogeny was an important step toward a better comprehension of polychelidan diversity. However, the description of new morphotypes of polychelidans implies that we now require a more complete phylogeny with more focus on fossil species. A preliminary phylogeny focused on fossil polychelidans was recently proposed by Audo (2014), however, more work is required to assess the reliability of these early results. Yet, following these initial results, Gabaleryon seems to be closely related to Proeryon and Tethyseryon (Audo 2014). It is therefore an important step to understand phylogenetic relationships among polychelidans. 
D. Audo et al.

\section{Acknowledgements}

We are greatly indebted to Nathalie Coquel-Poussy (Brenoux, France), who discovered specimens of Gabaleryon coquelae, proposed the first description of Brenoux outcrop and donated the holotype to MNHN; without her work and generosity, this study would not have been possible. We also thank David Gluck (Sessenheim, France), Tobias Klöck (Kaufbeuren, Germany) and Giuseppe Gulisano (Immenstadt im Allgäu, Germany), amateur palaeontologists, who discovered the specimens of Sennecey-le-Grand (DG) and Pfronten (TK, GG) and shared their discoveries with us. We are grateful to Alessandro Garassino (MSNM, Milano, Italy) for the access to the palaeontological collections, his help accessing Italian bibliography and his useful comments during the review of this article. We also acknowledge our second, anonymous reviewer for the comments on this work. We acknowledge the important contribution of Àlex Osso (Taragona, Spain) who suggested the study of the specimen from Sennecey-le-Grand and Arnaud Brayard (Université de Bourgogne, Dijon, France) who provided information on the datation of Sennecey-le-Grand.

\section{References}

Agassiz, L. 1833-1845. Recherches sur les poissons fossiles 1, $188 \mathrm{pp}$.

Aguirre-Urreta, M. B., Buatois, L. A., Chernoglasov, G. C. B. \& Medina, F. A. 1990. First Polychelidae (Crustacea, Palinura) from the Jurassic of Antarctica. Antarctic Science, 2(2), 157-162.

Ahyong, S. T. 2009. The Polychelidan Lobster: Phylogeny and Systematics (Polychelida : Polychelidae). Pp. 369-396 in J. W. Martin, K. A. Crandall \& D. L Felder (eds) Decapod Crustacean Phylogenetics. Crustacean Issues, Volume 18. Boca Raton, London, New York, CRC Press, Taylor \& Francis Group.

Allison, P. A. 1986. Soft-bodied animals in the fossil record: the role of decay in fragmentation during transport. Geology, 14(12), 979-981.

Allison, P. A. 1988. The role of anoxia in the decay and mineralization of proteinaceous macro-fossils. Paleobiology, 14(2), 139-154.

Audo, D. 2014. Les Polychelida, un groupe de crustacés énigmatiques : systématique, histoire évolutive, paléoécologie et paléoenvironnements. Muséum national d'Histoire naturelle. Unpublished $\mathrm{PhD}$ thesis, $298 \mathrm{pp}$. 
Audo, D., Charbonnier, S., Schweigert, G. \& Saint Martin, J.-P. 2014a. New eryonid crustaceans from the Late Jurassic Lagerstätten of Cerin (France), Canjuers (France), Wattendorf (Germany) and Zandt (Germany). Journal of Systematic Palaeontology, 12(4), 459-479.

Audo, D., Schweigert, G., Haug, J.T., Haug, C., Saint Martin, J.-P. \& Charbonnier, S., 2014b. Diversity and palaeoecology of the enigmatic genus Knebelia (Eucrustacea, Decapoda, Eryonidae) from Upper Jurassic plattenkalks in Southern Germany. Palaeontology, 57(2), 397-416.

Audo, D., Schweigert, G., Saint Martin, J.-P., Charbonnier, S. 2014c. High biodiversity in Polychelida crustaceans from the Jurassic La Voulte-sur-Rhône Lagerstätte. Geodiversitas, 36(4), 489-525.

Balss, H. 1924. Studien an fossilen Decapoden II. Paläontologische Zeitschrift, 6(2), 174184.

Bassoulet, J. P., Poisson, A., Elmi, S., Cecca, F., Bellion, Y., Guiraud, R., Le Nindre, Y. M. \& Manivit, J. 1993. Middle Toarcian Palaeoenvironments (184 to $182 \mathrm{Ma}$ ). In: Dercourt, J., Ricou, L. E. \& Vrielynck, B. (eds) Atlas Tethys Palaeoenvironmental Maps. Maps. BEICIP-FRANLAB, Rueil Malmaison.

Beurlen, K. 1928. Die Decapoden des Schwäbischen Jura mit Ausnahme der aus den oberjurassischen Plattenkalken stammenden. Beiträge zur Systematik und Stammesgeschichte der Decapoden. Palaeontographica, 70, 115-278, pls 6-8.

Beurlen, K. 1930. Nachträge zur Decapodenfauna des Schwäbischen Jura. Neues Jahrbuch für Mineralogie, Geologie und Paläontologie. Beilage-Bände, 64, 219-234.

Beurlen, K. 1944. Neue Reste von Proeryon (Crustacea, Decapoda, Eryonidea). Neues Jahrbuch für Mineralogie, Geologie und Paläontologie, Abhandlungen, Abteilung B: Geologie, Paläontologie, 88, 374-384.

Boulila, S., Galbrun, B., Huret, E., Hinnov, L.A., Rouget, I., Gardin, S. \& Bartolini, A. 2014. Astronomical calibration of the Toarcian Stage: Implications for sequence stratigraphy and duration of the early Toarcian OAE. Earth and Planetary Science Letters, 386, 98-111.

Bravi, S., Garassino, A., Bartiromo, A., Audo, D., Charbonnier, S., Schweigert, G., Thévenard, F. \& Longobardi, C. 2014. Middle Jurassic Monte Fallano Plattenkalk (Campania, southern Italy): first report on terrestrial plants, fishes, and decapod crustaceans. Neues Jahrbuch für Geologie und Paläontologie Abhandlungen, 272(1), 79-107. 
Broderip W. J. 1835. Description of some Fossil Crustacea and Radiata. Proceedings of the Geological Society of London, 2, 201-202.

Bronn, H. G. 1830. Ueber zwei fossile Fischarten: Cyprinus coryphaenoides und Tetragonolepis semicinctus aus dem Gryphitenkalke bei Donau-Eschingen. Jahrbuch für Mineralogie, Geognosie, Geologie und Petrefaktenkunde, 1(1), 14-30.

Bronn, H. G. 1842. Untersuchung zweier Gavial-Skelette und der Gaumen zweier anderer aus den Boller Lias-Schiefern, Rücksicht auf Geoffroy's Genus Teleosaurus. Pp. 5-30 in Bronn, H. G. \& Kaup, J. J. (eds) Abhandlungen über die gavialartigen Reptilien der Lias-Formation, Stuttgart, Schweizerbart.

Bronn H. G. 1858. Beiträge zur triasischen Fauna und Flora der bituminösen Schiefer von Raibl. Neues Jahrbuch für Mineralogie, Geognosie, Geologie und Petrefakten-Kunde, 1858, 1-32.

Burkenroad, M. D. 1963. The evolution of the Eucarida, (Crustacea, Eumalacostraca), in relation to the fossil record. Tulane Studies in Geology, 2(1), 2-17.

Caine, H. \& Benton, M. J. 2011. Ichthyosauria from the Upper Lias of Strawberry Bank, England. Palaeontology, 54(5), 1069-1093.

Cartes, J. E. \& Abelló, P. 1992. Comparative feeding habits of polychelid lobsters in the Western Mediterranean deep-sea communities. Marine Ecology Progress Series, 84(2), 139-150.

Caruthers, A. H., Smith, P. L. \& Gröcke, D. R. 2013 The Pliensbachian-Toarcian (Early Jurassic) extinction, a global multi-phased event. Palaeogeography, Palaeoclimatology, Palaeoecology, 386, 104-118.

Chan, T.-Y. 2010. Annotated checklist of the world's marine lobsters (Crustacea: Decapoda: Astacidea, Glypheidea, Achelata, Polychelida). Raffles Bulletin of Zoology, Supplement 23, 153-181.

Chernyshev, B. 1930. New Eryonidae from Vilui River. Izvestija Vsesojuznoe geologorazuedochinoe upavlenie, 49, 375-384 [in Russian]

Copp, C., Taylor, M. \& Thackray, J. 1999. Charles Moore (1814-1881), Somerset geologist. Proceedings of Somerset Archaeological and Natural History Society, 140, 1-36.

Coquel-Poussy, N. 2013. Recherches paléontologiques dans le Toarcien basal de la Lozère. Fossiles, 15, 5-15.

Danise, S., Twitchett, R.J. \& Little, C.T.S. 2015. Environmental controls on Jurassic marine ecosystems during global warming. Geology, 43, 263-266. 
Delfino, M. \& Dal Sasso, C. 2006. Marine reptiles (Thalattosuchia) from the Early Jurassic of Lombardy (northern Italy). Geobios, 39(3), 346-354.

Desmarest, A.-G. 1817. Crustacés fossiles. Pp. 495-519 in Société de Naturalistes et d'Agriculteurs (eds) Nouveau Dictionnaire d'Histoire naturelle, appliquée aux Arts, à l'Agriculture, à l'Économie rurale et domestique, à la Médecine, etc. Tome 7 [CORCUN]. Déterville, Paris.

Emmanuel, L., Renard, M., Cubaynes, R., De Rafelis, M., Hermoso, M., Lecallonnec, L, Le Solleuz, A. \& Rey, J. 2006. The "Schistes Carton" of Quercy (Tarn, France): a lithological signature of a methane hydrate dissociation event in the early Toarcian. Implications for correlations between Boreal and Tethyan realms. Bulletin de la Société Géologique de France, 177(5), 239-249.

Feistmantel, O. 1877. Note on "Eryon comp. barrovensis" McCoy from the Sripermatur Group near Madras. Records of the Geological Survey of India, 10(4), 193-196.

Feldmann, R. M., Schweitzer, C. E. \& Haggart, J. W. 2013. A new genus and species of polychelid lobster (Crustacea, Decapoda, Eryonidae) from the Early Jurassic (Hettangian) of British Columbia. Canadian Journal of Earth Sciences, 50(2), 135141.

Feldmann, R. M., Schweitzer, C. E., Karasawa, H., Schweigert, G. \& Garassino, A. 2013. Part R, Revised, Volume 1, Chapter 8G: Systematic descriptions: Infraorder Polychelida. Treatise Online 60, 1-10, 6 figs.

Firth, R. M. \& Pequegnat, W. E. 1971. Deep-sea lobsters of the families Polychelidae and Nephropidae (Crustacea, Decapoda) in the Gulf of Mexico and Caribbean Sea. Texas A \& M University, Department of Oceanography, 106 pp.

Fraas O. 1855. Beiträge zum obersten weissen Jura in Schwaben. Jahreshefte des Vereins für vaterländische Naturkunde in Württemberg, 11, 77-107.

Gaetani, M \& Poliani, G. 1978. Il Toarciano e il Giurassico medio in Albenza (Bergamo). Rivista Italiana di Paleontologia e Stratigrafia, 84(2), 349-382, pls 29-30.

Galil, B. S. 2000. Crustacea Decapoda: Review of the genera and species of the family Polychelidae Wood-Mason, 1874. Pp. 285-387 in A. Crosnier (ed.) Résultats des Campagnes MUSORSTOM, Volume 21. Mémoires du Muséum national d'Histoire naturelle, 184. Publications scientifiques du Muséum, Paris.

Garassino, A. \& Gironi, B. 2005. Proeryon hartmanni (v. Meyer, 1835) (Crustacea, Decapoda, Eryonoidea) and Archaeopalinurus cfr. A. levis Pinna, 1974 (Crustacea, Decapoda, Palinuroidea) from the Lower Jurassic (Toarcian) of Cesana Brianza-Suello 
(Lecco, N Italy). Atti della Società italiana di Scienze naturali e del Museo civico di Storia naturale in Milano, 146(1), 53-68.

Garassino, A. \& Gironi, B. 2006. Coleia boboi n. sp. (Crustacea, Decapoda, Eryonoidea) from the Late Triassic (Rhaetian) of Monte Verzegnis (Udine, NE Italy). Atti della Società italiana di Scienze naturali e del Museo civico di Storia naturale in Milano, 147(1), 93-102.

Garassino, A. \& Schweigert, G. 2006. The Upper Jurassic Sonhofen decapod crustacean fauna: review of the types from old descriptions. Part I. Infraorders Astacidea, Thalassinidea, and Palinura. Memorie della Società Italiana di Scienze Naturali e del Museo Civico di Storia Naturale di Milano, 34(1), 1-64.

Garassino, A. \& Teruzzi, G. 1993. A new decapod crustacean assemblage from the Upper Triassic of Lombardy (N. Italy). Paleontologia Lombarda, nuova serie, 1, 3-27.

Garassino, A. \& Teruzzi, G. 2001. I crostacei decapodi del Toarciano (Giurassico inferiore) di Sogno (Bergamo, N Italia). Atti della Società italiana di Scienze naturali e del Museo civico di Storia naturale in Milano, 141(2), 187-197.

Garassino, A., Teruzzi, G. \& Dalla Vecchia, F. M. 1996. The macruran decapod crustaceans of the Dolomia di Forni (Norian, Upper Triassic) of Carnia (Udine, NE Italy). Atti della Società italiana di Scienze naturali e del Museo civico di Storia naturale in Milano, 136(1), 15-60.

García Joral, F. Gómez, J. J. \& Goy, A. 2011. Mass extinction and recovery of the Early Toarcian (Early Jurassic) brachiopods linked to climate change in Northern and Central Spain. Palaeogeography, Palaeoclimatology, Palaeoecology, 302(3-4), 367380.

Glaessner, M. F. 1929. Crustacea Decapoda. Pp. 1-464 in F. J. Pompeckj (ed.) Fossilium Catalogus I: Animalia, Pars 41. W. Junk, Berlin.

Glaessner, M. F. 1969. Decapoda. Pp. R400-R533. In R. C. Moore and C. Teichert (eds). Treatise on Invertebrate Paleontology, Part R. Arthropoda, 4(2). Geological Society of America, Boulder, Colorado and University of Kansas Press, Lawrence, Kansas.

Golonka, J. 2007. Late Triassic and Early Jurassic palaeogeography of the world. Palaeogeography, Palaeoclimatology, Palaeoecology, 244, 297-307.

Gore, R.H. 1984. Abyssal Lobsters, Genus Willemoesia (Palinura, Polychelidae), from the Venezuela Basin, Caribbean Sea. Proceedings of the Academy of Natural Sciences of Philadelphia, 136, 1-11. 
Gould, C. 1857. Description of a new fossil crustacean (Tropifer lcevis, C. Gould) from the Lias Bone-bed. The Quarterly Journal of the Geological Society of London, 13(1), 360-363.

Haan, W., de 1833-1850. Crustacea. Pp. 1-243 in Ph. F. von Siebold (ed.) Fauna Japonica sive descriptio animalium, quae in itinere per Japoniam, jusse et auspiciis superiorurn, qui summum in India Batavia Imperium tenent, suscepto, annis 18231830 collegit, notis observationibus et adumbrationibus illustravit. A. Arnz, Lugdunum Batavorum.

Hauff, B. \& Hauff, R. B. 1981. Das Holzmadenbuch. Hauff-Stiftung, Holzmaden, 136 pp.

Haug J. T., Audo D., Charbonnier S., Haug C., Abi Saad P. \& Petit G. 2015. Unique occurrence of polychelidan lobster larvae in the fossil record and its palaeo-evo-devo implications. Gondwana Research, 28(2), 869-874.

Hendrickx, M. E. 2001. Occurrence of a continental slope decapod crustacean community along the edge of the minimum oxygen zone in the south eastern Gulf of California, Mexico. Belgian Journal of Zoology, 131 (Supplement 2), 95-110

Huang, C. J. \& Hesselbo, S. P. 2014. Pacing of the Toarcian Anoxic Event (Early Jurassic) from astronomical correlation of marine sections. Gondwana Research, 25, 13481356.

Jacobshagen, V. 1965. Die Allgäu-Schichten (Jura-Fleckenmergel) zwischen Wettersteingebirge und Rhein. Jahrbuch der Geologischen Bundesanstalt, 108, 1-114.

Karasawa, H., Takahashi, F., Doi, E. \& Ishida H. 2003. First notice of the family Coleiidae Van Straelen (Crustacea: Decapoda: Eryonoidea) from the Upper Triassic of Japan. Paleontological Research, 7(4), 357-362.

Knebel, W., von 1907. Die Eryoniden des oberen Weissen Jura von Süddeutschland. Archiv für Biontologie, 2(2), 195-233.

Krause, P. G. 1891. Die Decapoden des norddeutschen. Jura. Zeitschrift der Deutschen Geologischen Gesellschaft, 43(1), 171-225, pls 11-14.

Kuhn, O. 1952. Neue Crustacea Decapoda und Insecta aus dem untersten Lias $\varepsilon$ von Nordfranken. Palaeontographica, Abteilung A, 101(5-6), 153-166.

Lagardère, J.-P. 1973. Distribution des Décapodes dans le sud du Golfe de Gascogne. Revue des Travaux de l'Institut des Pêches Maritimes, 37(1), 77-95.

Lang, F. 2012. Seelilien aus dem Mitteljura von Süd-Burgund. Updated at: http://www.steinkern.de/fundorte/frankreich/257-seelilien-aus-dem-mitteljura-vonsued-burgund.html, accessed 18 September 2015. 
D. Audo et al.

Latreille, P. A. 1802. Histoire naturelle, générale et particulière, des Crustacés et des Insectes. Volume 3. F. Dufart, Paris, 468 pp.

Levitski, E. C. 1974. Fossil decapod crustaceans from the vicinity of the Bakhchisarai (the Crimea). Byulletin Moskovskogo Obshchestva Ispytatelei Prirody Otdel Geologicheskii, 49(6), 101-119. [in Russian]

Little, C. T. S. \& Benton, M. J. 1995. Early Jurassic mass extinction: A global long-term event. Geology, 23, 495-498.

Macchioni, F. \& Cecca, F. 2002. Biodiversity and biogeography of the middle-late Liassic ammonoids: implications for the early Toarcian mass extinction. Geobios, 35 (Suppl. 1): $165-175$.

Marek, R., Moon, B. C., Williams, M. \& Benton, M. J. 2015. The skull and endocranium of a Lower Jurassic ichthyosaur based on digital reconstructions. Palaeontology, 58, http://doi.org/10.1111/pala.12174.

Meyer, C. A. 1990. Depositional environment and palaeoecology of creinoid-communities from the Middle Jurassic Burgundy-Platform of Western Europe. Pp. 25-32 in C. De Ridder, P. Dubois, M.-C. Lahaye \& M. Jangoux (eds) Echinoderm Research. Balkema, Rotterdam.

Meyer, H., von 1836. Beiträge zu Eryon, einem Geschlechte fossiler langschwänziger Krebse. Nova Acta Physico-Medica Academiae Caesareae Leopoldino-Carolinae Naturae Curiosorum, 18(1), 263-283.

Moore, C. 1866. On the Middle and Upper Lias of the South-West of England. Proceedings of Somerset Archaeological and Natural History Society, 13,119-244.

Morière, J. 1864. Note sur les crustacés fossiles des terrains jurassiques du Calvados. Bulletin de la Société Linnéenne de Normandie, 8, 89-96.

Morière, J. 1883. Note sur une Eryonidée nouvelle trouvée à la Caine (Calvados). Bulletin de la Société Linnéenne de Normandie, 3e Série, 7, 116-122.

Münster, G., Graf zu 1839. Decapoda Macroura. Abbildung und Beschreibung der fossilen langschwänzigen Krebse in den Kalkschiefern von Bayern. Beiträge zur Petrefaktenkunde, 2, 1-88.

Oppel, A. 1861. Die Arten der Gattungen Eryma, Pseudastacus, Magila und Etallonia. Jahreshefte des Vereins für Vaterländische Naturkunde in Württemberg, 17, 355-361.

Oppel, A. 1862. Über jurassische Crustaceen (Decapoda macrura). Palaeontologische Mittheilungen aus dem Museum des koeniglich Bayerischen Staates, 1, 1-120. 
Pellenard, P.E., Thiry-Bastien, P., Thierry, J. \& Vincent, B. 1998. Approche sédimentologique du Bajocien supérieur-Bathonien inférieur du nord-ouest de la Bourgogne (sud-est du bassin de Paris : dynamique sédimentaire et reconstruction paléogéographique d'un secteur d'une plate-forme carbonatée péri-téthysienne. Géologie de la France, 1, 21-38.

Pierce, S. \& Benton, M. J. 2006. Pelagosaurus typus Bronn, 1841 (Mesoeucrocodylia: Thalattosuchia) from the Upper Lias (Toarcian; Lower Jurassic) of Somerset, England. Journal of Vertebrate Paleontology, 26, 621-635.

Pinna, G. 1968. Gli Erionidei della nuova fauna sinemuriana a crostacei decapodi di Osteno in Lombardia. Atti della Società italiana di Scienze naturali e del Museo civico di Storia naturale in Milano, 107(2), 93-134.

Pinna, G. 1969. Due nuovi esemplari di Coleia viallii Pinna, del Sinemuriano inferiore di Osteno in Lombardia. Annali del Museo Civico di Storia Naturale di Genova, 77, 626632.

Plotnick, R. E. 1986. Taphonomy of a modern shrimp: implications for the arthropod fossil record. Palaios, 1(3), 286-293.

Scholtz, G. \& Richter, S. 1995. Phylogenetic systematics of the reptantian Decapoda (Crustacea, Malacostraca). Zoological Journal of the Linnean Society, 113(3), 289328.

Schweigert, G., Garassino, A., Hall, R. L., Hauff, R. B. \& Karasawa, H. 2003. The lobster genus Uncina Quenstedt, 1851 (Crustacea: Decapoda: Astacidea: Uncinidae) from the Lower Jurassic. Stuttgarter Beiträge zur Naturkunde, Serie B, 332, 1-43

Schweitzer, C. E., Feldmann, R. M., Garassino, A., Karasawa, H. \& Schweigert, G. 2010. Systematic list of fossil decapod crustacean species. Crustaceana Monographs, 10, 1-222.

Spence Bate, C. 1888. Report on the Crustacea Macrura collected by H.M.S. Challenger during the years 1873-1876. Pp. 1-942 in C. Wyville Thomson \& J. Murray (eds) Report on the scientific results of the voyage of the H.M.S. Challenger during the years 1873-76 under the command of Captain Georges S. Nares R.N., F.R.S. and the late Captain Frank Tourle Thomson, R.N. Zoology. Volume 24. Neill, Edinburgh.

Suan, G., Mattioli, E., Pittet, B., Lécuyer, C., Suchéras-Marx, B., Duarte, L. V., Philippe, M. Reggiani, L. \& Martineau, F. 2010. Secular environmental precursors to Early Toarcian (Jurassic) extreme climate changes. Earth and Planetary Science Letters, 290(3-4), 448-458. 
Teruzzi, G. 1990. The genus Coleia Broderip, 1835 (Crustacea, Decapoda) in the Sinemurian of Osteno in Lombardy. Atti della Società italiana di Scienze naturali e del Museo civico di Storia naturale in Milano, 131(4), 85-104.

Teruzzi, G. \& Garassino, A. 2007. Coleia Broderip, 1835 (Crustacea, Decapoda, Coleiidae) from the Mesozoic of Italy: an update. Pp. 95-96 in Garassino, A., Feldmann, R. M. \& Teruzzi, G. (eds) 3rd Symposium on Mesozoic and Cenozoic decapod crustaceans. Memorie della Società Italiana di Scienze Naturali e del Museo Civico di Storia Naturale di Milano, 35(2), 95-96.

Tintori, A. 1977. Toarcian fishes from the lombardian basin. Bollettino della Società Paleontologica Italiana, 16(2), 143-152.

Van Straelen, V. 1923. Description de Crustacés décapodes macroures nouveaux des terrains secondaires. Annales de la Société royale zoologique de Belgique, 53, 84-93.

Van Straelen, V. 1925. Contribution à l'étude des crustacés décapodes de la période jurassique. Mémoires de la Classe des Sciences de l'Académie royale de Belgique, 7, $1-462$.

Vörös, A. 2002. Victims of the Early Toarcian anoxic event: the radiation and extinction of Jurassic Koninckinidae (Brachiopoda). Lethaia, 35(4), 345-357.

Wignall, P.B., Newton, R.J. \& Little, C.T.S. 2005. The timing of paleoenvironmental change and cause-and-effect relationships during the Early Jurassic mass extinction in Europe. American Journal of Science, 305, 1014-1032.

Williams, M., Benton, M. J. \& Ross, A. 2015. The Strawberry Bank Lagerstätte reveals insights into Early Jurassic life. Journal of the Geological Society. 172 (6) 683-692

Wills, M.A. 2001. How good is the fossil record of arthropods? An assessment using the stratigraphic congruence of cladograms. Geological Journal, 36(3-4), 187-210.

Wood-Mason, J. 1874. On Blind Crustaceans. Proceedings of the Asiatic Society of Bengal, $1874,180-181$.

Woods, H. 1925-1931. A monograph of the fossil macrurous crustacean of England. The Palaeontographical Society, London: 1-122, pls 1-27.

Woodward, H. 1866. Notes on the species of the genus Eryon Desmarest from the Lias and Oolite of England and Bavaria. Quarterly Journal of the Geological Society, 22, 494502.

Woodward, H. 1877. A Catalogue of British Fossil Crustacea, with their synonyms and the range in time of each genus and order. Taylor and Francis, London, 155 p. 
Woodward, H. 1881. Contribution to the study of Fossil Crustacea. The Geological Magazine New series Decade II, 8(12), 529-534.

Woodward, H. 1911. On a new species of Eryon from the Upper Lias, Dumbleton Hill. The Geological Magazine New series Decade V, 8(7), 307-311.

WoRMS 2015. Stereomastis Spence Bate, 1888. Accessed through: World Register of Marine Species at http://www.marinespecies.org/aphia.php?p=taxdetails\&id=107057 on 2015-07-26. 
D. Audo et al.

\section{Figures}

Figure 1. Generic and specific diversity of polychelidans across time with indication of major Fossil-Lagerstätten in which they occur. References: basis for record, Audo (2014); 1, Ahyong (2009), Chan (2010) and WoRMS (2015); 2, Galil (2000).

Figure 2. Palaeogeographical map of Western Europe during the mid-Toarcian (simplified after Bassoulet et al. 1993) and location of Brenoux (1), Strawberry Bank (2), Outcrops from Sogno Formation (3), Engetal valley (4). Abbreviations: A, Apulia; ACP, Apennine carbonate platform; Al, Alborán; AM, Armorican Massif; Dm, Dalmatia; IM, Iberian Meseta; K, Kabylia; LBM, London-Brabant Massif; MC, Massif Central; TP, Tisza Plate; Trp, Trento Plateau; TuB, Tuscany Basin.

Figure 3. Comparison of the general outline of carapaces and third pleonite (right sides omitted) of the type species of each genus of fossil Polychelida: A, Adamanteryon fourneti Audo, Schweigert, Saint Martin \& Charbonnier, 2014; B, Antarcticheles antarcticus AguirreUrreta, Chernoglasov \& Medina 1990; C, Coleia antiqua Broderip, 1835; D, Cycleryon propinquus (Schlotheim, 1822); E, Eryon cuvieri Desmarest, 1817; F, Gabaleryon coquelae nov. gen., nov. sp.; G, Hellerocaris falloti (Van Straelen, 1923); H, Knebelia bilobata (Münster, 1839); I, Palaeopentacheles roettenbacheri (Münster, 1839); J, Palaeopolycheles longipes (Fraas, 1855); K, Proeryon hartmanni (Meyer, 1836); L, Pseudocoleia mazzolenii Garassino \& Teruzzi, 1993; M, Rosenfeldia triasica Garassino, Teruzzi \& Dalla Vecchia, 1996; N, Soleryon amicalis Audo, Charbonnier, Schweigert \& Saint Martin, 2014; O, Tethyseryon campanicus Bravi, Garassino, Bartiromo, Audo, Charbonnier, Schweigert, Thévenard \& Longobardi, 2014; P, Tetrachela raiblana (Bronn, 1858); Q, Tropifer laevis Gould, 1857; R, Voulteryon parvulus Audo, Schweigert, Saint Martin \& Charbonnier, 2014; S, Willemoesiocaris ovalis (Van Straelen, 1923); T, Wrangelleryon perates Feldmann, Schweitzer \& Haggart, 2013. Illustrations not to scale.

Figure 4. Gabaleryon coquelae nov. gen., nov. sp. from the early Toarcian of Brenoux, France. A-B, holotype MNHN.F. A51506, part, dorsal view in cross-polarized light (A) and interpretative line-drawing (B). C-D, paratype (N. Coquel-Poussy pers. coll.) part, ventral view in UV-light (C) and interpretative line-drawing (D). Abbreviations: a1, antennula; a2, antenna; ba, uropodal basipodite; bc, branchial carina; c, postcervical groove; ca, carpus; ci, postcervical incision; da, dactylus; di, diaeresis; e1e, cervical groove; en, uropodal endopod; ex, uropodal exopod; me, merus; mxp3, third maxilliped; o, eye; P1-P5, pereiopods 1 to 5; 
P?, indeterminate pereiopod; pc, postcervical carina; po, postorbital carina; pr, postrostral carina; pro, propodus; px, pollex; s1-s6, pleonites 1 to 6; sc, scaphocerite; t, telson Scale bars, $1 \mathrm{~cm}$. Photographs, D. Audo (A) and P. Loubry (C).

Figure 5. Gabaleryon moorei (Woodward, 1866) nov. comb. from the early Toarcian of Strawberry Bank, United Kingdom. A, holotype BRLSI M1247, dorsal view. B, interpretative line-drawing. Abbreviations: a1, antennula; a2, antenna; ba, uropodal basipodite; bc, branchial carina; c, postcervical groove; da, dactylus; di, diaeresis; en, uropodal endopod; ex, uropodal exopod; P1, pereiopod 1; po, postorbital carina; s1-s6, pleonites to 6; sc, scaphocerite; t, telson. Scale bars, $1 \mathrm{~cm}$. Photograph, M. Williams.

Figure 6. Gabaleryon garassinoi nov. gen., nov. sp. from mount Cornizzolo, Italy. A-B, holotype MSNM i26215, part, dorsal view in cross-polarized light (A) and interpretative linedrawing (B). C-D, paratype MSNM i26211 interpretative line-drawing (C) and part, dorsal view, cross-polarized light (D). E, paratype (MSNM i26284), ventral view, cross-polarized light. Abbreviations: a2, antenna; ba, uropodal basipodite; c, postcervical groove; ca, carpus; da, dactylus; di, diaeresis; e1e, cervical groove; en, uropodal endopod; ex, uropodal exopod; md, mandible; me, merus; o, eye; P1, pereiopod 1; pro, propodus; px, pollex; s1-s6, pleonites 1 to 6; sc, scaphocerite; t, telson. Scale bars, $1 \mathrm{~cm}$. Photographs, D. Audo, copyright MSNM.

Figure 7. Gabaleryon garassinoi nov. gen., nov. sp. from mounts Cornizzolo and Brughetto, Italy. A-B, paratype MSNM i26214 from mount Cornizzolo, dorsal view, crosspolarized light (A) and interpretative line-drawing (B). C-D, paratype MSNM i10850 from mount Brughetto, dorsal view (C) and interpretative line-drawing (D). Abbreviations: a, branchiocardiac groove; a1, antennule; a2, antenna; ba, uropodal basipodite; bc, branchial carina; c, postcervical groove; da, dactylus; di, diaeresis; en, uropodal endopod; e1e, cervical groove; ex, uropodal exopod; o, eye; P1-P5, pereiopod 1 to 5; P?, indeterminate pereiopod; pc, postcervical carina; pr, postrostral carina; px, pollex; s1-s6, pleonite 1 to 6 ; $\mathbf{t}$, telson. Scale bars, $1 \mathrm{~cm}$. Photographs, D. Audo (A) and A. Garassino (MSNM) (B), both copyright MSNM.

Figure 8. Other probable occurrences of Gabaleryon nov. gen. A, Gabaleryon sp. 1 from the Toarcian of Pfronten, Germany, natural light, with superimposed interpretative linedrawing. B, ?Gabaleryon sp. 2 from the late Bajocian - early Bathonian of Sennecey-leGrand, France, dorsal-view in cross-polarized light. Scale bars, $1 \mathrm{~cm}$. Photographs, Tobias Klöck (A) and D. Audo (B). 
Figure 1

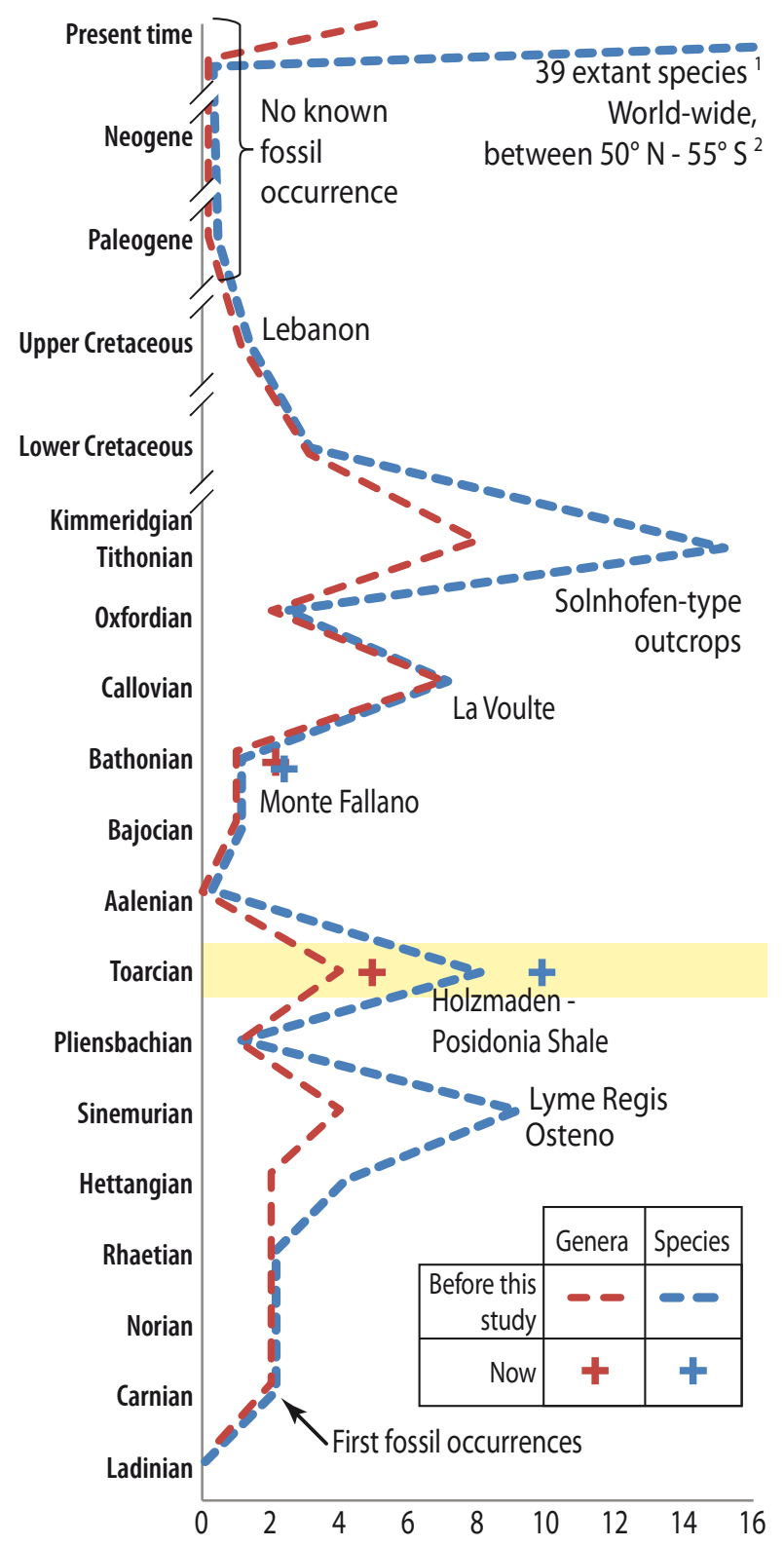


Figure 2

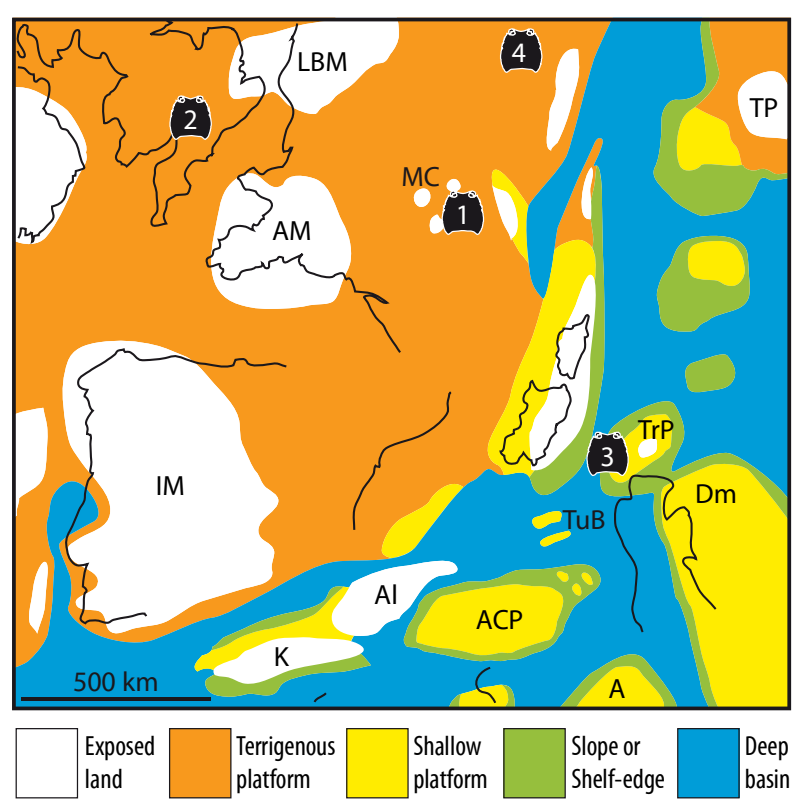


Figure 3

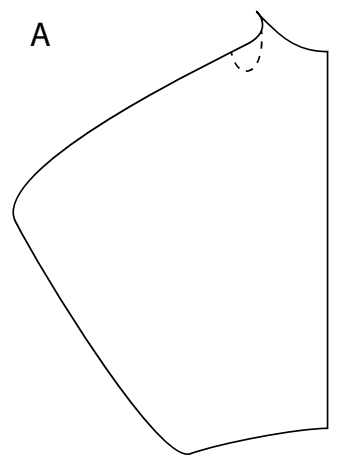

Adamanteryon

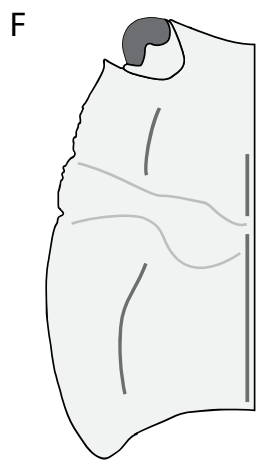

Gabaleryon

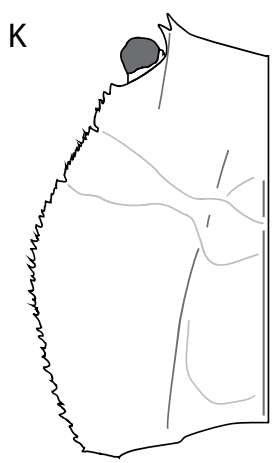

Proeryon

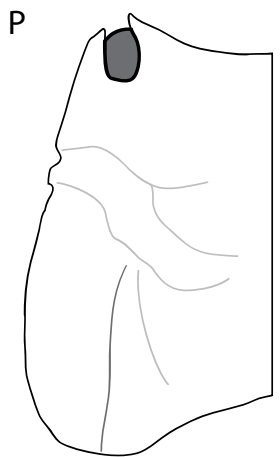

Tetrachela
B

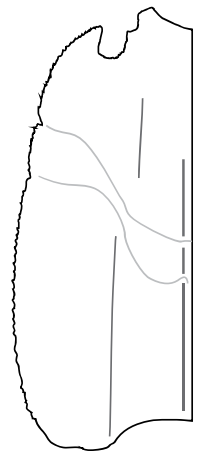

Antarcticheles

G

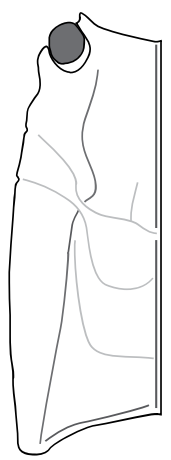

Hellerocaris

L

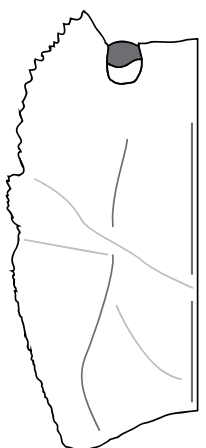

Pseudocoleia

Q

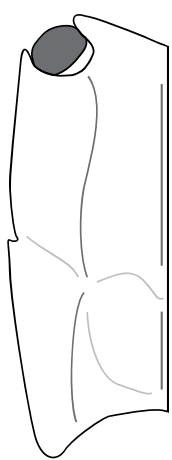

Tropifer

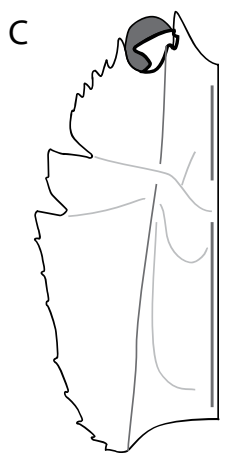

Coleia

$\mathrm{H}$

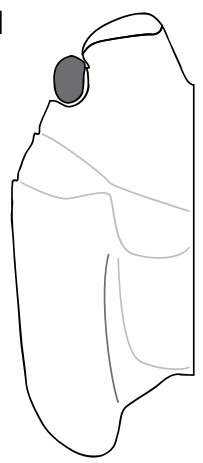

Knebelia

M

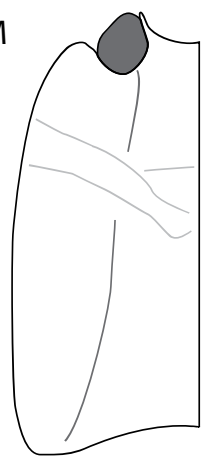

Rosenfeldia

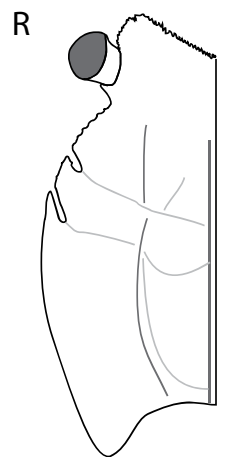

Voulteryon

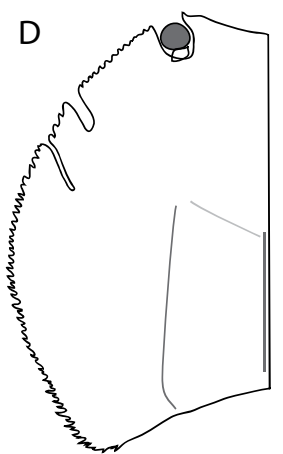

Cycleryon

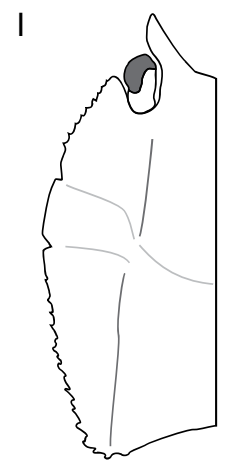

Palaeopentacheles

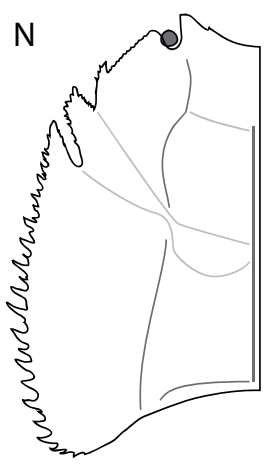

Soleryon

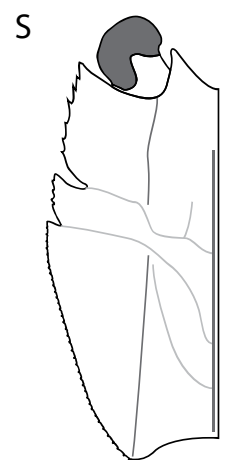

Willemoesiocaris

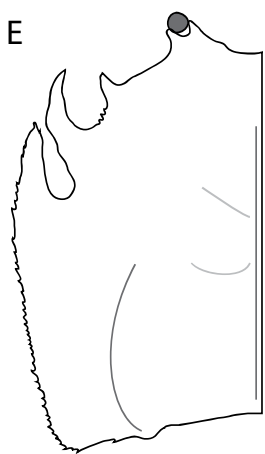

Eryon

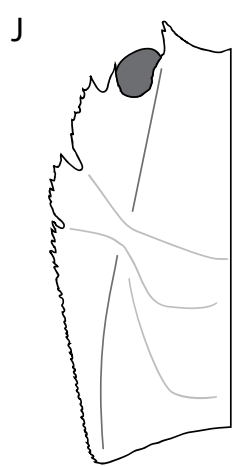

Palaeopolycheles

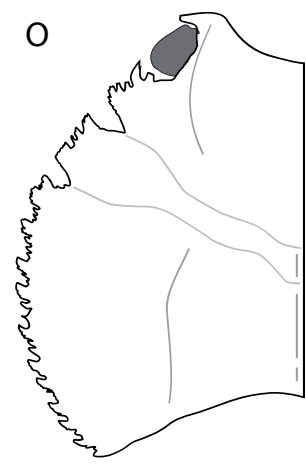

Tethyseryon

T

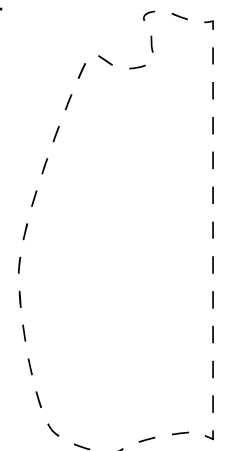

Wrangelleryon 
Figure 4

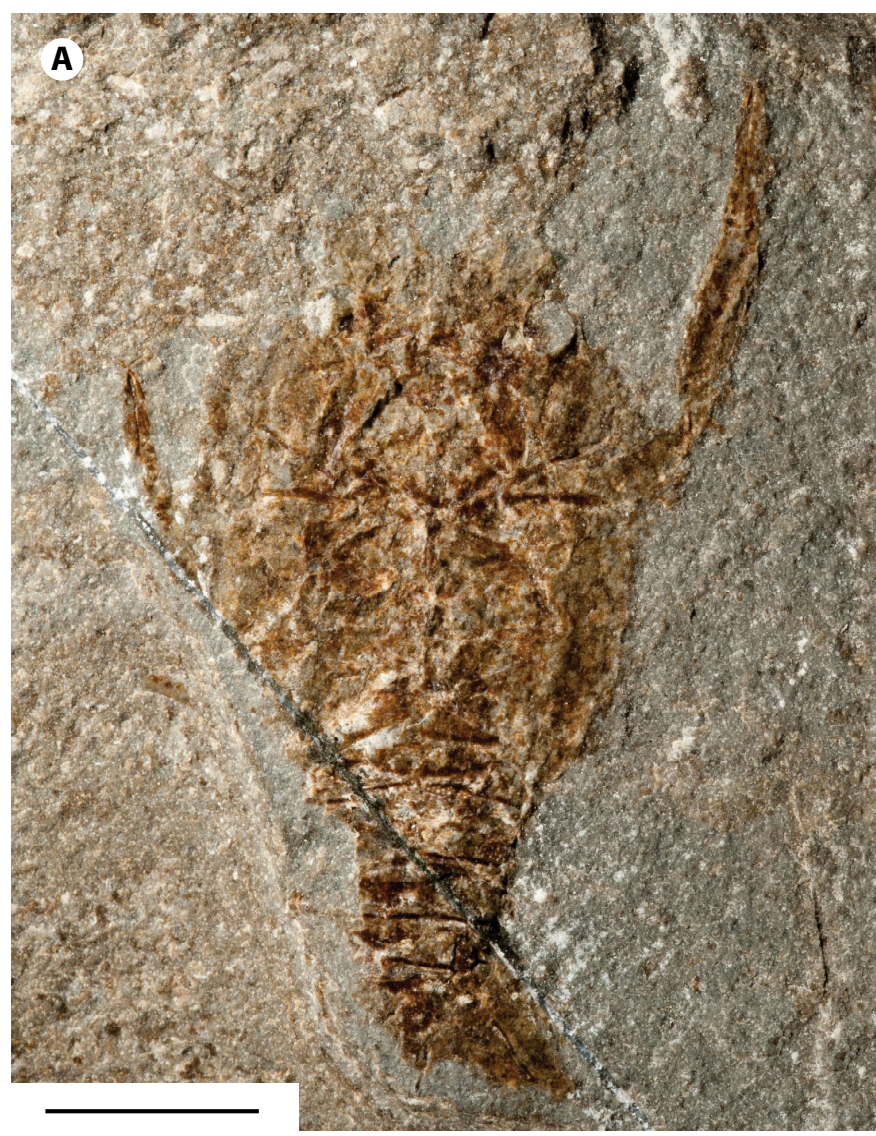

B
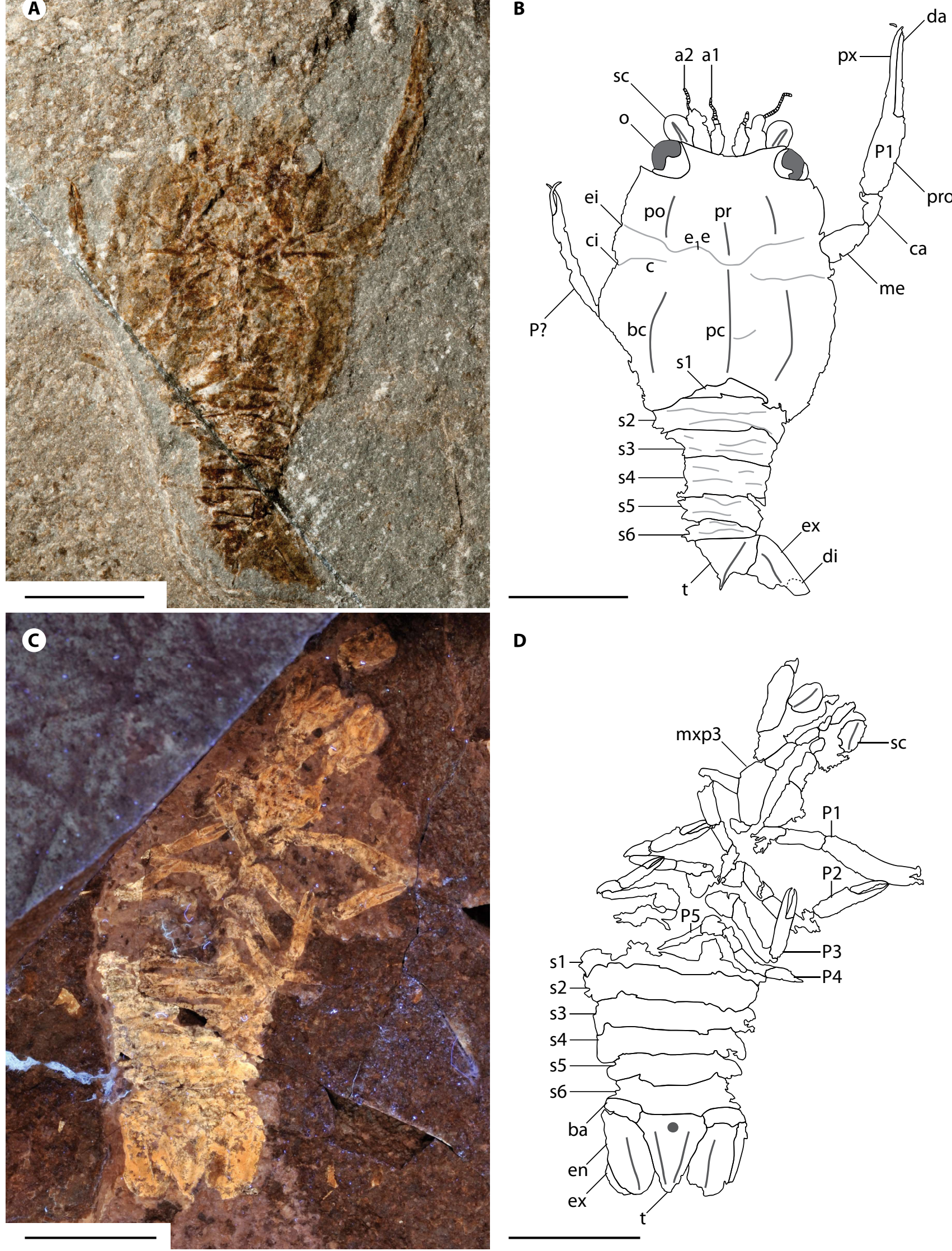

D

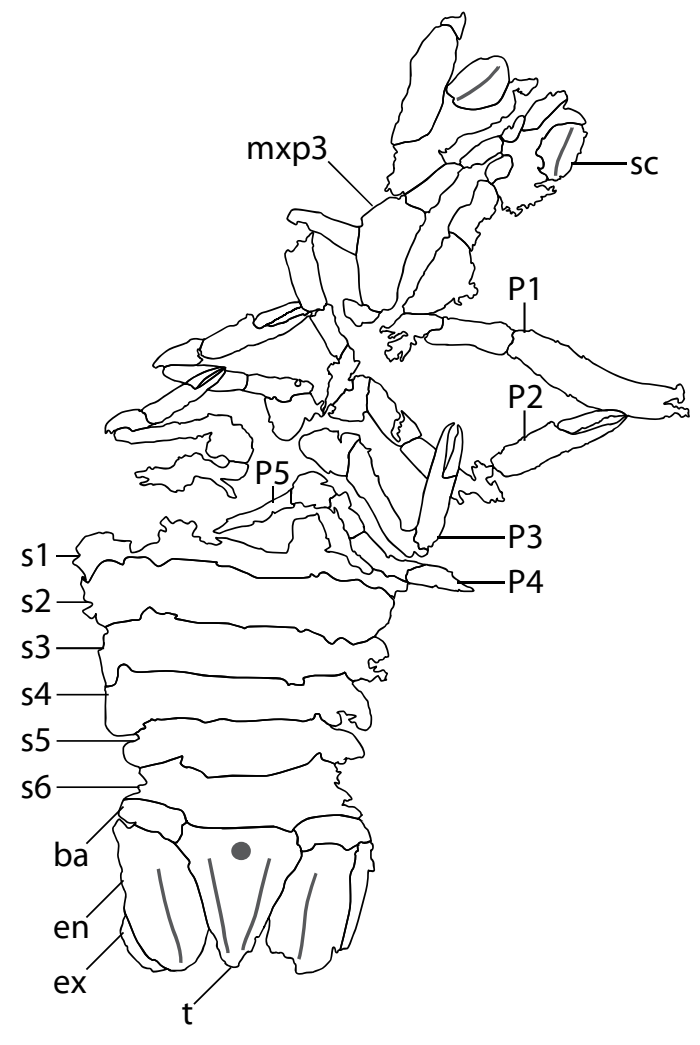


Figure 5
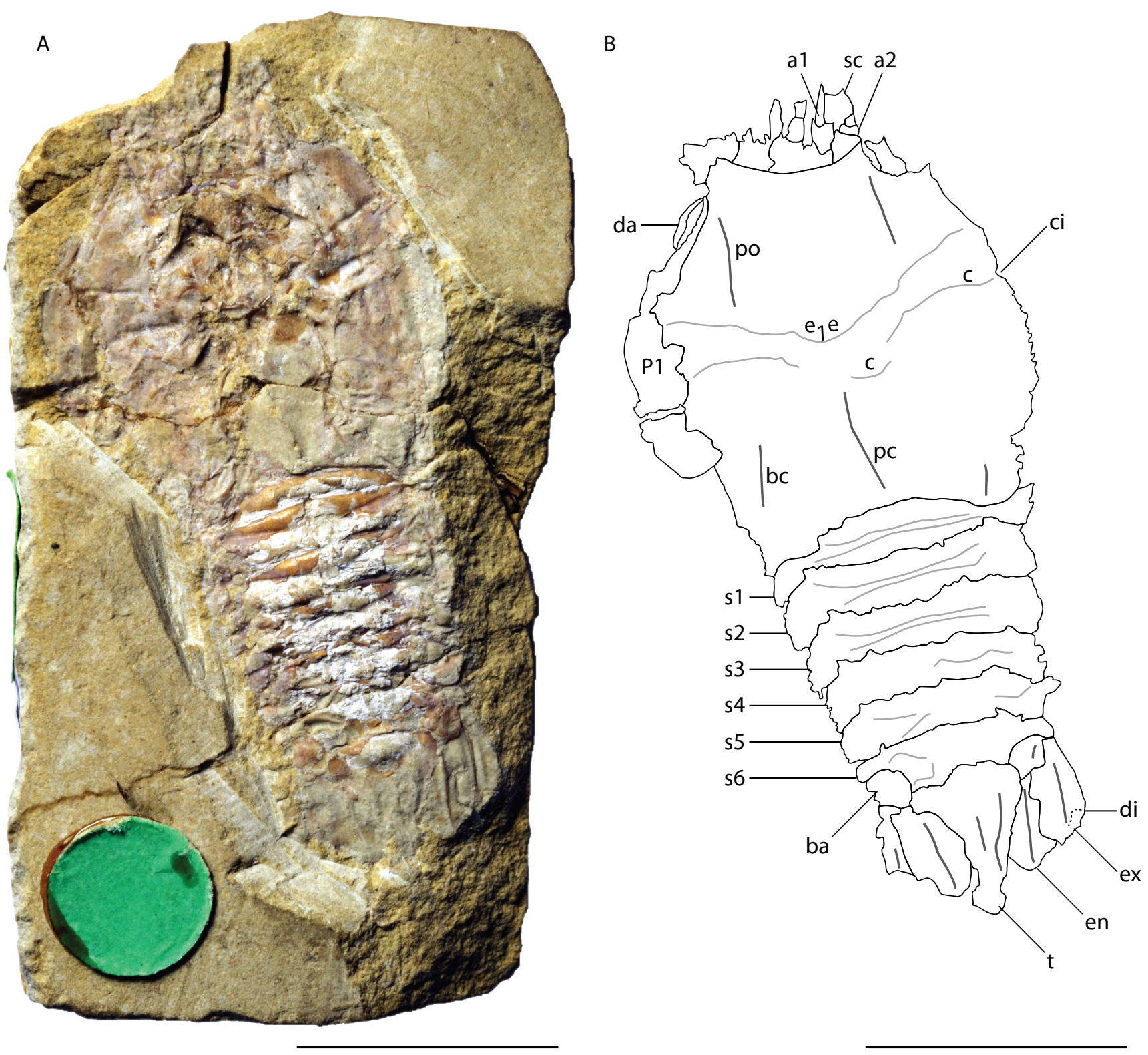
Figure 6
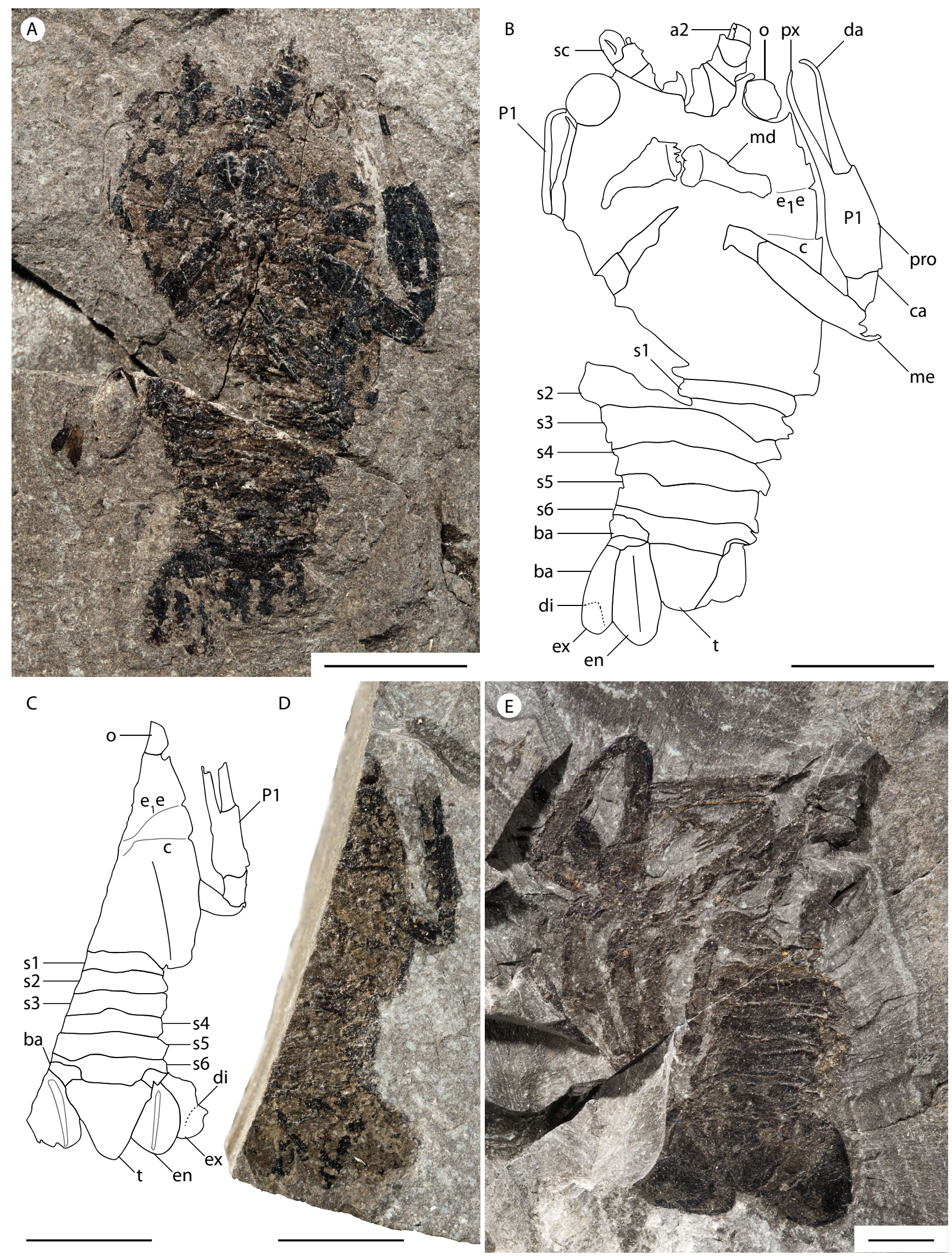
Figure 7

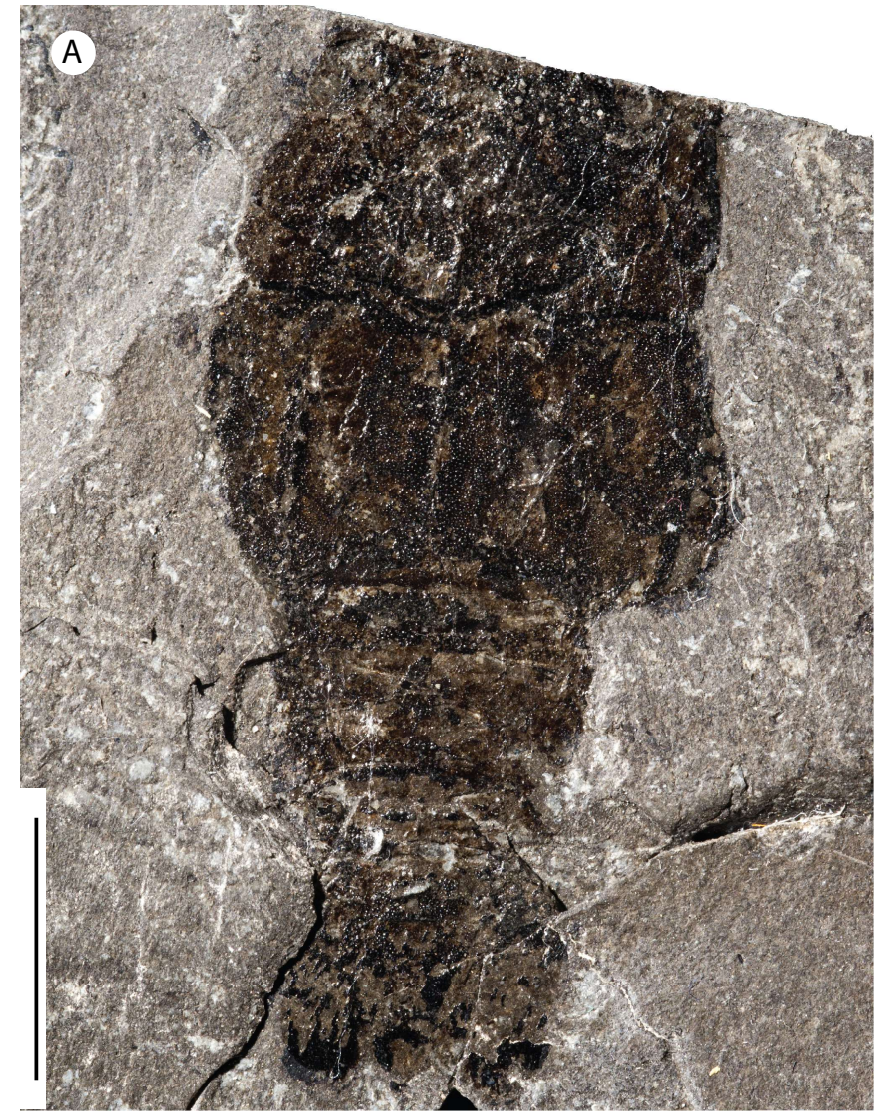

B
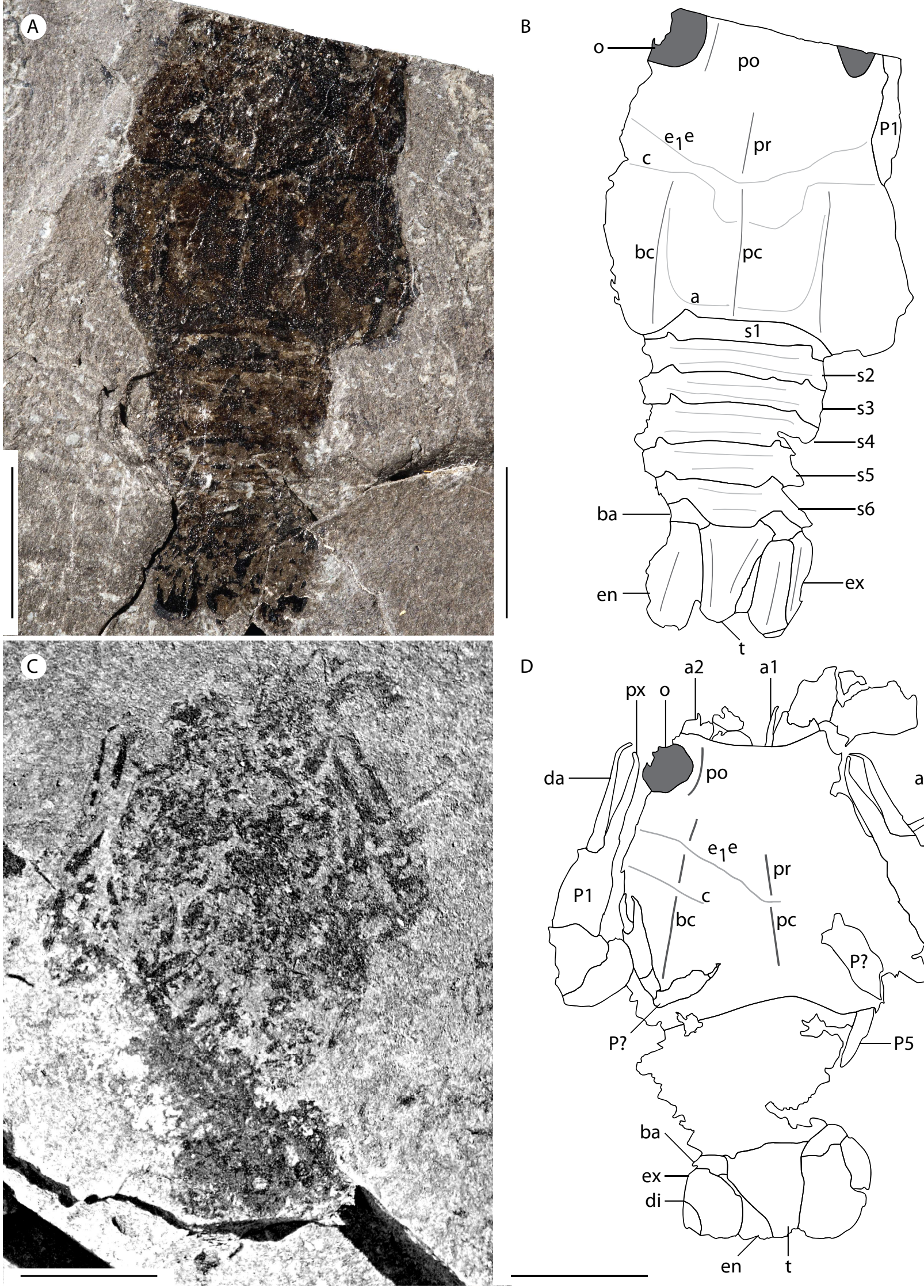

D

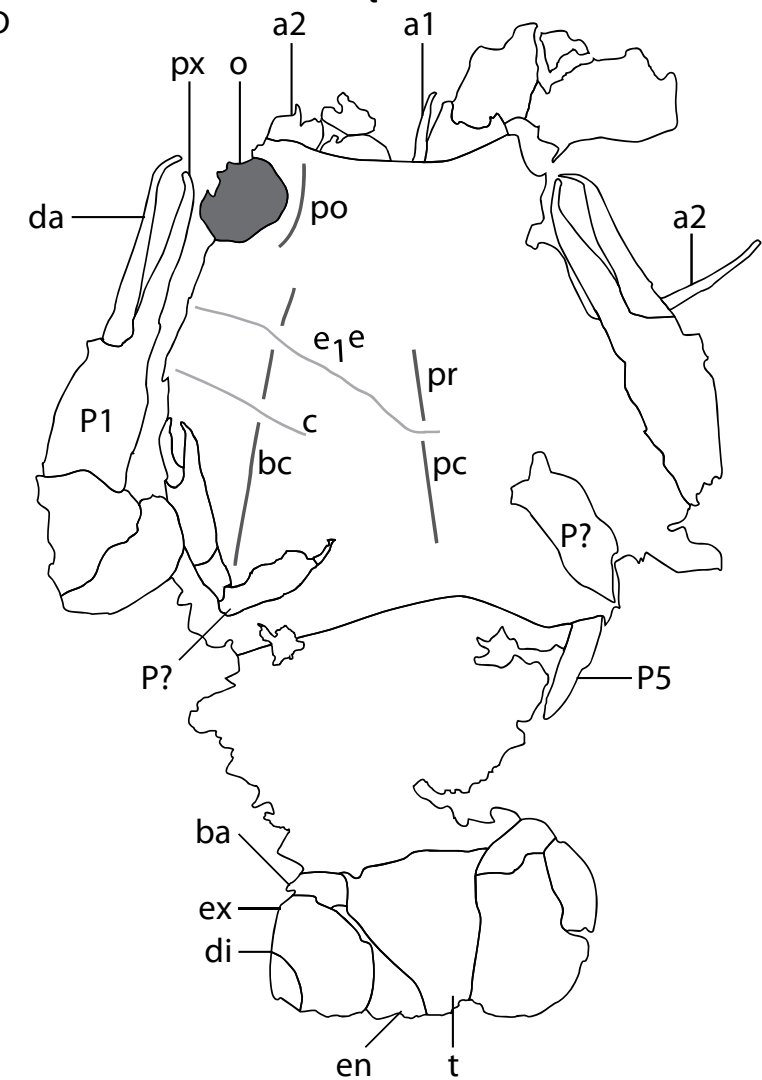


Figure 8

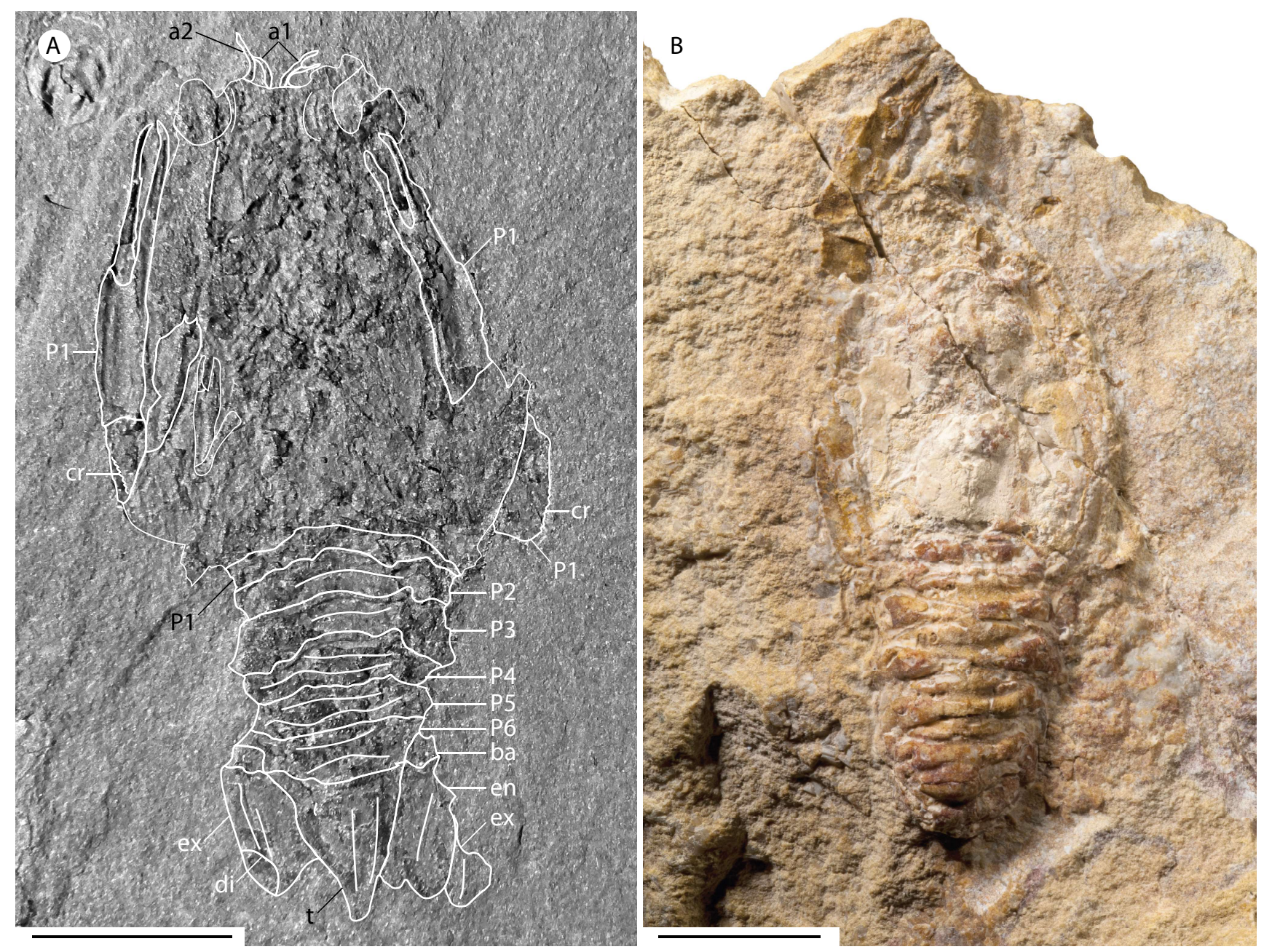

